\title{
Application of MCDM Methods in Sustainability Engineering: A Literature Review 2008-2018
}

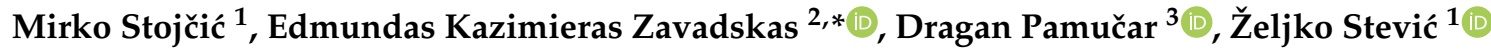 \\ and Abbas Mardani ${ }^{4}$ \\ 1 Faculty of Transport and Traffic Engineering, University of East Sarajevo, Vojvode Mišića 52, 74000 Doboj, \\ Republic of Srpska, Bosnia and Herzegovina; mirkostojcic1@hotmail.com (M.S.); zeljkostevic88@yahoo.com \\ or zeljko.stevic@sf.ues.rs.ba (Ž.S.) \\ 2 Institute of Sustainable Construction, Vilnius Gediminas Technical University, Sauletekio al. 11, \\ LT-10223 Vilnius, Lithuania \\ 3 Department of Logistics, University of Defence in Belgrade, Pavla Jurišića Šturma 33, 11000 Belgrade, Serbia; \\ dpamucar@gmail.com \\ 4 Azman Hashim International Business School, Universiti Teknologi Malaysia (UTM), Skudai Johor 81310, \\ Malaysia; mabbas3@liveutm.onmicrosoft.com \\ * Correspondence: edmundas.zavadskas@vgtu.lt
}

Received: 16 February 2019; Accepted: 5 March 2019; Published: 8 March 2019

\begin{abstract}
Sustainability is one of the main challenges of the recent decades. In this regard, several prior studies have used different techniques and approaches for solving this problem in the field of sustainability engineering. Multiple criteria decision making (MCDM) is an important technique that presents a systematic approach for helping decisionmakers in this field. The main goal of this paper is to review the literature concerning the application of MCDM methods in the field of sustainable engineering. The Web of Science (WoS) Core Collection Database was chosen to identify 108 papers in the period of 2008-2018. The selected papers were classified into five categories, including construction and infrastructure, supply chains, transport and logistics, energy, and other. In addition, the articles were classified based on author, year, application area, study objective and problem, applied methods, number of published papers, and name of the journal. The results of this paper show that sustainable engineering is an area that is quite suitable for the use of MCDM. It can be concluded that most of the methods used in sustainable engineering are based on traditional approaches with a noticeable trend towards applying the theory of uncertainty, such as fuzzy, grey, rough, and neutrosophic theory.
\end{abstract}

Keywords: sustainability; engineering; multi-criteria decision-making

\section{Introduction}

The emergence of the concept of sustainability has been motivated by natural catastrophes, environmental contamination, depletion of natural resources, and other incidents. According to Our Common Future (Brundtland Report) adopted by the World Commission on Environment and Development in 1987 [1], sustainability implies an integrative concept that includes environmental, economic, and social aspects. These three aspects are often referred to as the three pillars of sustainability. In this way, sustainability has become a modern principle that explains the long-term relationship between the present and future generations [2]. At the same time, the term "sustainable development' has emerged, which implies "meet[ing] the needs of the present generation without compromising the ability of future generations to meet their own needs" [3]. Although there are many definitions of sustainable development [4], this is one of the most frequently quoted. In order to 
achieve the balance between the three pillars of sustainability, it is necessary to define the links and interactions between them, i.e., it is necessary to know how they influence each other [5].

In order to achieve sustainability, sustainable engineering is proposed as a potential solution that implies the application of different methods. Examples may include the construction of facilities made of materials that provide energy efficiency, finding energy forms that do not release carbon dioxide into the atmosphere, designing electric vehicles, etc. According to some authors, sustainable engineering implies significantly more serious considerations of environmental and social aspects [6]. Sustainable engineering thereby observes the system as part of a global ecosystem. According to Abraham [7], the following basic principles of sustainable engineering can be set out:

- Using system analysis and integrating environmental impact assessment tools;

- Improving natural ecosystems;

- Using life cycle thinking;

- Using only material and energy inputs and outputs that are clean and safe;

- Minimizing the depletion of the natural resources;

- Preventing waste;

- Applying engineering solutions having in mind geographic area, culture, and aspirations;

- Creating innovation-based solutions;

- Involving all stakeholders and community in the process of developing solutions.

Engineering is the application of scientific and mathematical principles for practical objectives, such as the processes, manufacture, design, and operation of products, while accounting for constraints invoked by environmental, economic, and social factors. There are various factors needing to be considered in order to address engineering sustainability, which is critical for the overall sustainability of human development and activity. In recent decades, decision-making theory has been a subject of intense research activity [8], due to its wide applications in different areas, such as sustainable engineering and environmental sustainability. The decision-making theory approach has become an important means of providing real-time solutions to uncertainty problems, especially for sustainable engineering and environmental sustainability problems in engineering processes. In the recent decades, several techniques and methods have been used for solving problems in the areas of environmental sustainability and sustainable engineering. Multiple criteria decision making (MCDM) is an important method that has been applied in various areas of sustainable engineering. Several prior studies have employed MCDM techniques in different areas of sustainable engineering [9-18]. In addition, several prior papers have reviewed the application MCDM and fuzzy sets theory in different areas of engineering and sustainability [11,19-26].

The main goal of the paper is to review the literature regarding the application of MCDM methods in the field of sustainable engineering. Another goal is to synthesize different areas of engineering and show effective ways of solving various problems in the field by applying various MCDM methods in various forms of uncertainty. Moreover, this review can be very useful for other studies in various areas of sustainable engineering by showing how MCDM methods can be adequate tools for decision-making processes in sustainable engineering. Furthermore, this paper highlights new, important information for all the participants in MCDM processes in sustainable engineering. In addition, this paper, to the authors' knowledge, is the first review of the literature in the area of sustainable engineering from the perspective of the application of MCDM methods.

The remainder of the paper is structured as follows. Section 2 presents the methodology, in which our algorithm for collecting and processing the articles is presented and explained in detail. Section 3 discusses the primary results of the review, i.e., the total number of MCDM articles in the field of science and technology, with an emphasis on the field of sustainable engineering. The results have been presented by various areas and the structure of the published articles has been presented by journal. Section 4 provides a detailed review of various engineering fields including, construction and 
infrastructure, supply chains, transport and logistics, energy, and other. In this section, the application of MCDM methods in each of the above areas is explained in detail. Section 5 presents our conclusions.

\section{Methodology}

This paper reviews the collected literature on the topic of MCDM methods in sustainable engineering. In addition to searching in the Web of Science (WoS) Core Collection Database, articles were searched in online journal databases, using Google Scholar and the Google search engine using the following keywords: MCDM, sustainability, and sustainable engineering. Their combinations were also used when searching as follows: MCDM + sustainability + engineering, MCDM + sustainable engineering, $\mathrm{MCDM}+$ sustainability, and $\mathrm{MCDM}+$ engineering. All the collected articles were published in the period of 2008-2018. The research methodology is shown in Figure 1.

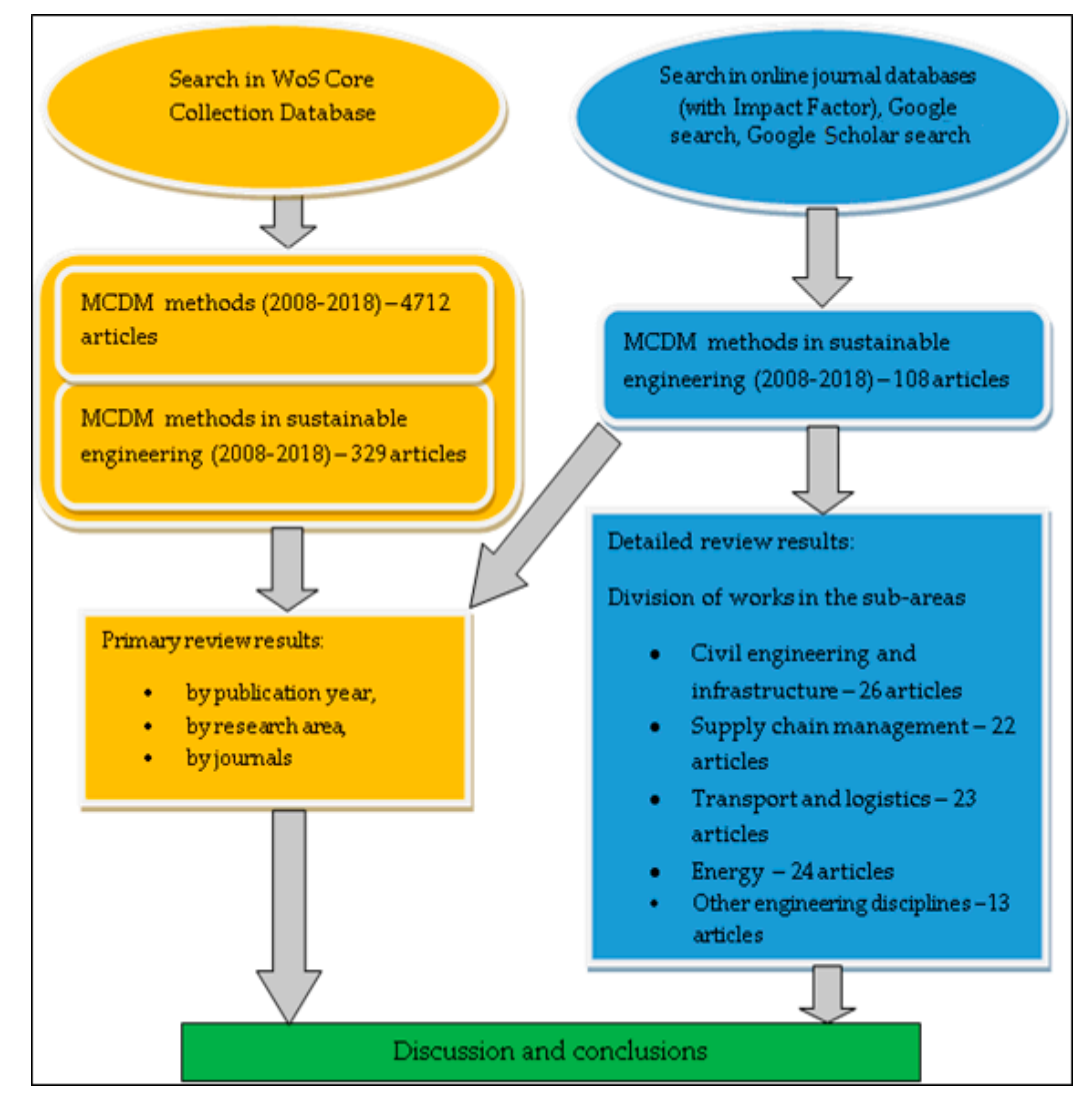

Figure 1. Brief research procedure.

By searching the WoS Core Collection Database, 4712 articles related to the application of MCDM methods in various fields of science and technology have been identified, of which 329 articles deal with the application of MCDM methods in sustainable engineering. In parallel, in the search of online journal databases with impact factors, 108 articles were found, and they were divided into five sub-areas. Based on this, the results of the primary review of articles (by publication year, by area, and by journal) are provided, while a detailed analysis and review of these articles are presented in Section 4.

\section{Primary Review Results}

By searching the Web of Science Core Collection database, 4712 articles (November 2018) dealing with the application of MCDM methods in various fields of science and technology were found, as shown in Figure 2. 


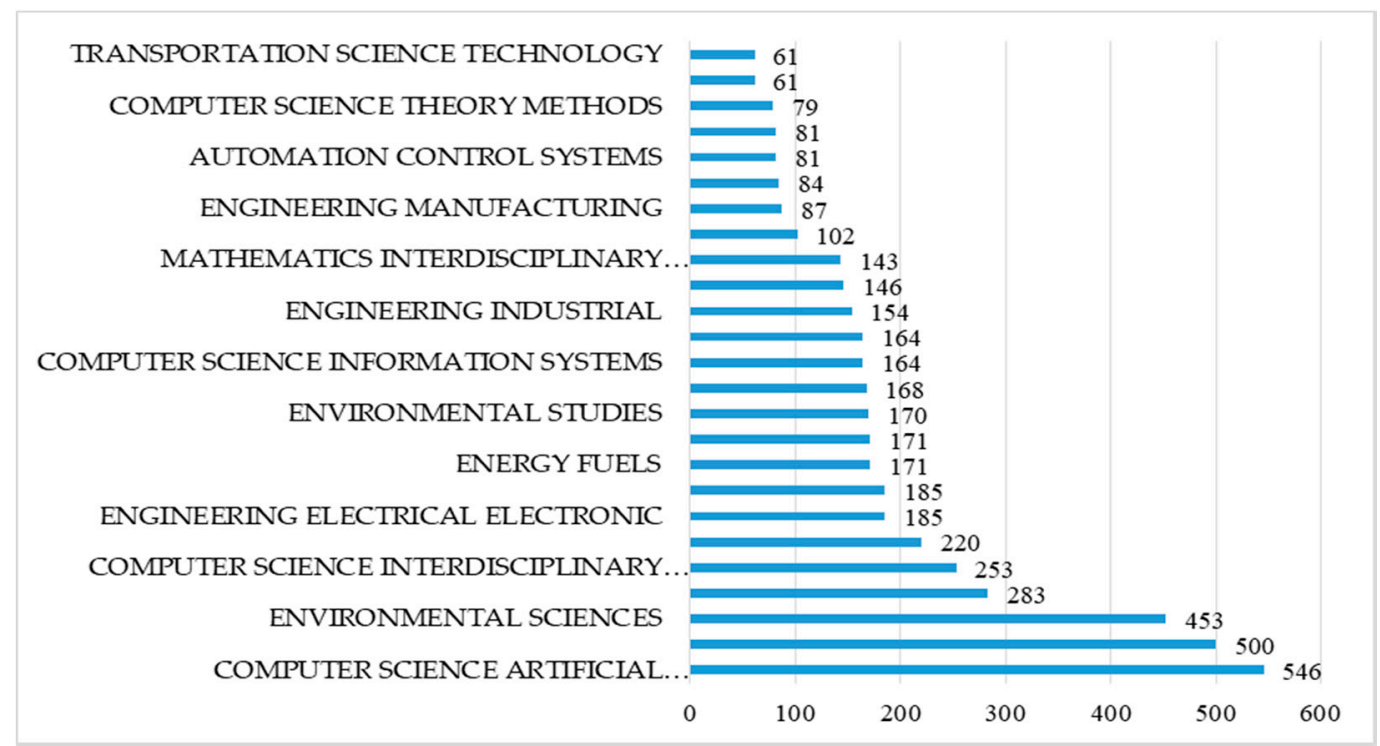

Figure 2. Number of articles on the application of multiple criteria decision making (MCDM) methods in various fields of science and technology.

Figure 2 shows the top 25 areas in which studies applying MCDM methods can be categorized, indicating the number of articles for each area. It appears that the largest number of articles belong to the field of computer science and artificial intelligence (546 articles), while the application of MCDM methods in operational research occupies the second position (500 articles). The smallest number of articles has been published in the field of transport technology (61). It can be concluded that these areas are currently up to date.

In terms of the articles on the application of MCDM methods in sustainable engineering, the Web of Science Core Collection database contains 329 articles, as shown in Figure 3.

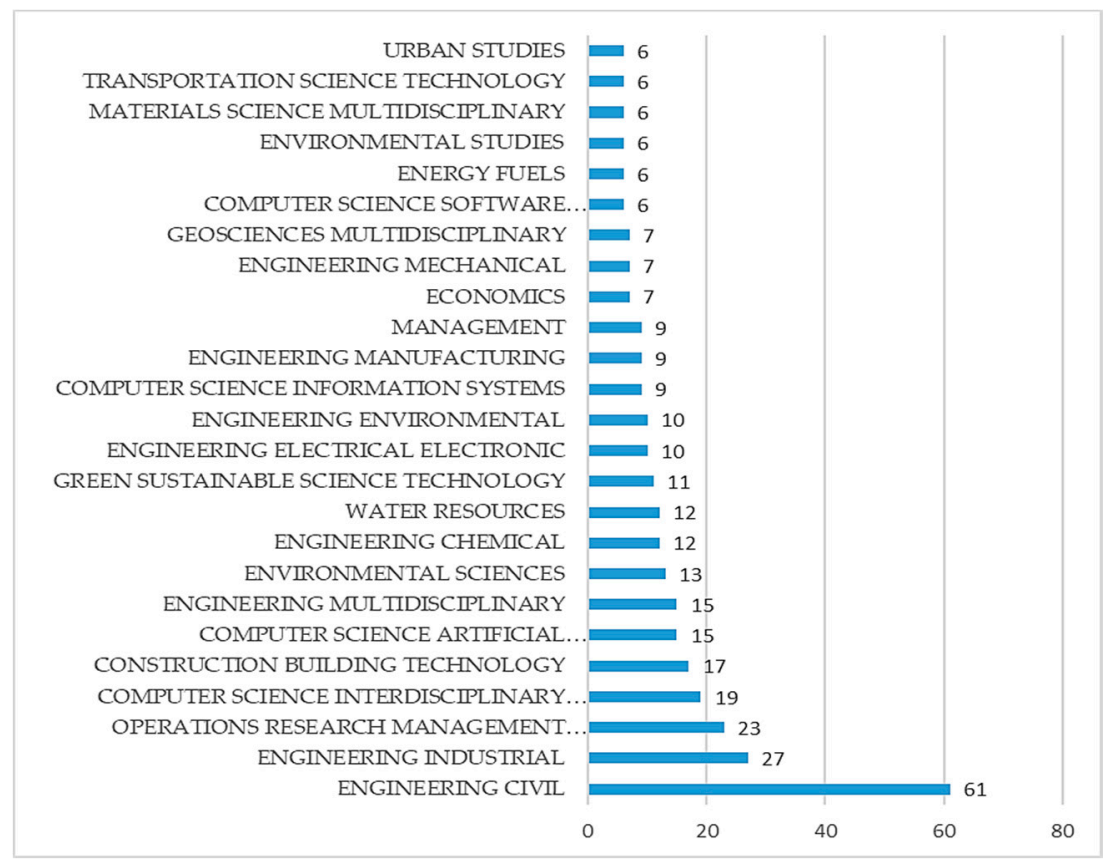

Figure 3. Number of articles on the application of MCDM methods in sustainable engineering.

Figure 3 shows the top 25 areas in which studies applying MCDM methods in sustainable engineering can be categorized. The largest number of articles belongs to the field of civil engineering 
(61), and the smallest number belongs to the fields of urban studies (6). It can be observed that the field of transportation science technology, materials science multidisciplinary, environmental studies, energy fuels and computer science software are also at the lower end. In the second position is the area of industrial engineering, followed by operational research, etc.

Figure 4 provides a review of the collected articles by publication years. There is an evident increase in the number of articles in the last few years, because environmental protection, waste minimization, renewable energy sources, energy efficiency, and the concept of sustainability in general have become increasingly frequent and significant subjects of research in many studies in the 21st century $[27,28]$. In addition, it appears that in 2008, there was not a single published article related to the application of MCDM methods in sustainable engineering.



Figure 4. Number of published (collected) articles on MCDM in sustainable engineering by years.

Table 1 provides an overview of the number of articles collected by particular journals.

Table 1. Number of articles by journals.

\begin{tabular}{ccc}
\hline Title of the Journal & Number of Articles & Percent \\
Sustainability & 14 & 12.96 \\
Journal of Cleaner Production & 10 & 9.26 \\
Energy & 9 & 8.33 \\
Transport & 5 & 4.63 \\
Applied Energy & 5 & 4.63 \\
Journal of Civil Engineering and Management & 5 & 4.63 \\
Energies & 4 & 3.70 \\
International Journal of Production Research & 4 & 3.70 \\
Construction and Building Materials & 4 & 3.70 \\
Clean Technologies and Environmental Policy & 4 & 3.70 \\
Energy Policy & 3 & 2.78 \\
Lransportation Research Part D: Transport and Environment & 2 & 1.85 \\
Renewable and Sustainable Energy Reviews & 2 & 1.85 \\
Land Use Policy & 2 & 1.85 \\
Ecological Economics & 1.85 \\
Water Resources Management & 2 & 1.85 \\
Water & 2 & 0.93 \\
International Journal of Information Technology Decision Making & 1 & 0.93 \\
Tunnelling and Underground Space Technology & 1 & 0.93 \\
Transportation Research Part A: Policy and Practice & 1 & 0.93 \\
Transtation Planning and Technology & 1 & 0.93 \\
Thechnological Forecasting and Social Change & 1 & 0.93 \\
Sustainable cities and society & 1 & 0.93 \\
Science of the Total Environment & 1 & 0.93 \\
\hline & 1 & 0.93 \\
\hline
\end{tabular}


Table 1. Cont.

\begin{tabular}{rcc}
\hline Title of the Journal & Number of Articles & Percent \\
\hline Journal of Manufacturing Systems & 1 & 0.93 \\
Journal of Infrastructure Systems & 1 & 0.93 \\
Journal of Environmental Planning and Management & 1 & 0.93 \\
International Journal of Uncertainty, Fuzziness and Knowledge-Based Systems & 1 & 0.93 \\
International Journal of Sustainable Transportation & 1 & 0.93 \\
International Journal of Production Economics & 1 & 0.93 \\
Expert systems with Applications & 1 & 0.93 \\
European Journal of Operational Research & 1 & 0.93 \\
European Journal of Environmental and Civil Engineering & 1 & 0.93 \\
Environmental Modelling \& Software & 1 & 0.93 \\
Economic Research & 1 & 0.93 \\
Decision support systems & 1 & 0.93 \\
Computers \& Structures & 1 & 0.93 \\
Computers \& Industrial Engineering & 1 & 0.93 \\
Computer-Aided Civil and Infrastructure Engineering & 1 & 0.93 \\
Civil Engineering and Environmental Systems & 1 & 0.93 \\
Cities & 1 & 0.93 \\
Building and environment & 1 & 0.93 \\
Automation in Construction & 1 & 0.93 \\
Applied Sciences & 1 & 0.93 \\
Applied Mathematical Modelling & 1 & 0.93 \\
AIChE Journal & 1 & 0.93 \\
\hline
\end{tabular}

Based on Table 1, it can be concluded that most of the collected articles have been published in the journal Sustainability (14 articles), which represents $12.96 \%$ of the total number. The Journal of Cleaner Production can be ranked second with 10 articles or $9.26 \%$ of the total articles. Out of a total of 47 journals, 31 have published one article related to MCDM methods in sustainable engineering. It is important to note that all these journals have impact factors.

\section{Detailed Review Results}

All the collected articles (108 articles) on the topic of applications of MCDM methods in sustainability engineering have been classified into 5 categories: construction and infrastructure, supply chains, transport and logistics, energy, and other. It is important to mention that some areas of engineering, such as mechanical engineering, have not been taken into consideration because of the lack of articles regarding such topics. For each of the above categories, a detailed analysis of the aim and importance of the application of the individual MCDM method has been provided, and the results of the review have also been given in a table. Figure 5 shows the subdivision into the 5 subcategories with the number of articles in each subcategory.

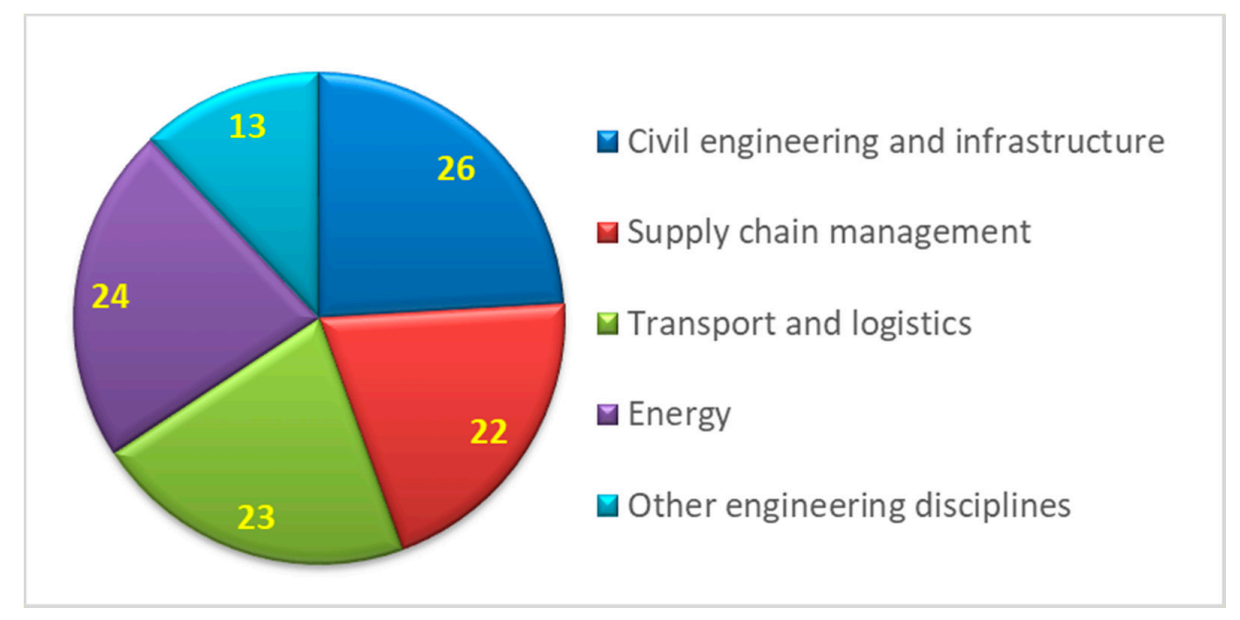

Figure 5. Division of research subjects into five sub-areas. 


\subsection{Civil Engineering and Infrastructure}

In the domain of architecture and construction, increasing attention is being paid to energy efficiency and smart buildings, and therefore, it is necessary to go towards sustainability in the design and construction of facilities and infrastructure. Consequently, it is required to select adequate materials as well. In this section, a detailed analysis of the 26 collected articles in the field of construction and infrastructure is presented.

In their work, Birgani and Yazdandoost [29] provided a framework for a new approach to addressing flood problems in urban areas. In many cases, due to unforeseen and abundant precipitation, the existing drainage network cannot receive large amounts of precipitation. For this reason, for the selection between several alternatives of the sewer system, an integrated approach that implies the sustainability and application of multi-criteria decision-making methods, i.e. the adaptive analytical hierarchy process (AHP), entropy and Technique for Order of Preference by Similarity to Ideal Solution (TOPSIS) was proposed. The framework was applied to the case study for a part of the city of Tehran, Iran. The problem of floods in urban areas due to abundant precipitation was also discussed in [30]. Based on the sustainability criteria, using the AHP method for determining the weights and the Preference Ranking Organization Method for the Enrichment of Evaluations II (PROMETHEE II) for the final ranking of the alternatives, a framework for the selection of an optimum drainage system was proposed. The implementation of the framework was carried out using the example of Buraydah City, Qassim, Saudi Arabia.

Construction is an area that interacts enormously with the natural environment. A large percentage of raw materials are obtained from the earth, and in their treatment and processing and the construction of buildings, certain environmental pollution is inevitable. Lombera and Rojo [31] use the Spanish MIVES (Integrated Value Model for Sustainable Assessment) methodology to define the criteria for the sustainability of industrial buildings and to select the optimum solution with regards to them. Generally speaking, the MIVES methodology combines multi-criteria decision-making and multi-attribute utility theory (MAUT), including a value function concept and weight assignment by the AHP method [32]. A similar study was presented in a study by del Cano et al. [33], in which authors also used the MIVES method but in combination with Monte Carlo simulation in order to assess the sustainability of concrete structures. For the same purpose, de la Fuente et al. [34] applied fuzzy-MIVES. Moreover, de la Fuente et al. [34] also applied the MIVES methodology together with the AHP method in order to reduce the subjective human impact on the selection of sewage pipe material. Akhtar et al. [35] solved the same problem using only the AHP method. The MIVES methodology was also used in a study by de la Fuente et al. [36], assessing the sustainability of alternatives-the types of concrete and their reinforcement for their application in tunnels, depending on environmental, social, and economic criteria. The case study was carried out for the city of Barcelona. Pons and de la Fuente [37] used MIVES to select the most suitable concrete pillars as structural components of buildings, while Pujadas et al. [32] constructed a framework for the evaluation of heterogeneous public investments using this methodology, which is a step towards sustainable urban planning. Different economic, environmental, and social aspects were considered, with five criteria and eight indicators.

The problem of monitoring, repairing, and the returning to function of steel bridge structures is a major challenge for engineers, especially because it is necessary to make key decisions, and wrongly made decisions can be very costly. In order to exclude subjectivity in selecting alternatives in this case, Rashidi et al. [38] presented the decision support system (DSS), in which the simplified AHP (S-AHP) method is used. S-AHP combines the simple multi-attribute rating technique (SMART) and the AHP method. The aim is to help engineers in planning the safety, functionality, and sustainability of steel bridge structures. Jia et al. [39] presented a framework for the selection of bridge construction between the accelerated bridge construction $(\mathrm{ABC})$ method and conventional alternatives, using TOPSIS and fuzzy TOPSIS methods.

In their work, Formisano and Mazzolani [40] presented a new procedure for the selection of the optimum solution for seismic retrofitting of existing reinforced concrete (RC) buildings, as well as 
optimum solutions for vertical upgrading of existing masonry constructions. The procedure involved the application of three MCDM methods, namely TOPSIS, elimination and choice expressing reality (ELECTRE), and VIseKriterijumska Optimizacija i Kompromisno Rešenje (VIKOR). In two case studies, these methods showed the same results. In their work, Terracciano et al. [41] selected cold-formed, thin-walled steel structures for vertical reinforcement and energy retrofitting systems of existing masonry constructions. The TOPSIS method for selecting alternatives based on structural, economic, environmental, and energy criteria was used.

Improving traditional buildings into modern ones must comply with technical regulations, energy requirements, comfort requirements, and the preservation of existing architecture. Siozinyte et al. [42] applied the AHP and TOPSIS grey MCDM methods to select the optimum solution for modernizing traditional buildings.

Khoshnava et al. [43] applied MCDM methods to select energy efficient, ecological, recyclable materials for building with respect to the three pillars of sustainability. In order to evaluate 23 criteria in the selection of materials, they used the decision-making trial and evaluation laboratory (DEMATEL) hybrid MCDM method together with the fuzzy analytic network process (FANP). Akadiri et al. [44] used fuzzy extended AHP (FEAHP) in order to select sustainable building materials.

In a study by Ozcan-Deniz and Zhu [45], the analytic network process (ANP) method was used to select the most environmentally friendly method for the construction of a highway, because such construction can have a great impact on the environment. Possible alternatives included different types of materials, operations, and project conditions. Constructing traffic infrastructure can greatly increase the level of safety for participants, but also reduce traffic jams. In their work, Stevic et al. [46] selected the locations for the construction of roundabouts using the rough best-worst method (BWM) and the rough weighted aggregated sum product assessment (WASPAS) approach based on the New Rough Hamy Aggregator.

In their work, Rashid et al. [47] used MCDM methods to select sustainable concrete, which implies a mixture of conventional coarse aggregate and ceramic waste aggregate. The AHP and TOPSIS methods were used to select the best performing concrete in terms of the pressure it can endure and its impact on the environment.

During and even after the construction of facilities, a large amount of natural resources is used, which adversely affects the environment. Most systems for evaluating the sustainability of facilities take into account only the environmental aspect and the environmental impact. However, it is necessary to take into account all three basic principles of sustainability, and thus Raslanas et al. [48], in their work, developed a system for evaluating the sustainability of recreational facilities, using the AHP method. Because so-called "green buildings" are environmentally friendly, attention is increasingly being given to the selection of methods for their construction. Taking into account that this is a very complex task, the application of MCDM methods is indispensable, and in the study by Tsai et al. [49], DEMATEL, ANP, and zero-one goal programming (ZOGP) methods were applied.

The selection of construction project managers plays a key role for the entire construction process. Zavadskas et al. [50] used the MCDM approach to this problem and applied AHP and additive ratio assessment (ARAS) methods. The alternatives were selected based on the criteria of education, experience, and personal abilities and skills.

When building larger facilities, i.e., implementing capital projects, it is very important to select a proper transport route for the procurement of raw materials and materials. Marzouk and Elmesteckawi [51] selected the best alternative for the construction of a power plant using the SMART method.

Because the number of vehicles on the roads is increasing every day, the number of parking spaces can hardly follow this trend. Using the MCDM method, Palevicius et al. [52] indicated the worst parking conditions in Vilnius, Lithuania, with all three aspects of sustainability, using simple additive weighting (SAW), TOPSIS, complex proportional assessment (COPRAS), and AHP method. Table 2 summarizes the applied MCDM methods in the sub-area of civil engineering and infrastructure. 
Table 2. MCDM methods in the sub-area of civil engineering and infrastructure.

\begin{tabular}{|c|c|c|}
\hline A Problem that Is Solved Using the MCDM Method & Applied Methods & Reference \\
\hline Evaluating urban drainage plans in terms of their sustainability and resilience & $\begin{array}{l}\text { Adaptive AHP, Entropy, } \\
\text { TOPSIS }\end{array}$ & [29] \\
\hline Assessment of sustainability criteria of industrial buildings & AHP, MIVES & [31] \\
\hline Assessing sustainability adopted by the Spanish Structural Concrete Code (EHE) & AHP, MIVES & [33] \\
\hline Assessing sustainability adopted by the Spanish Structural Concrete Code (EHE) & Fuzzy MIVES & [34] \\
\hline Sustainability analysis of different constituent materials for sewerage pipes & AHP, MIVES & [34] \\
\hline $\begin{array}{c}\text { Evaluating and comparing of four typical sewer pipe materials and identifying a } \\
\text { sustainable solution }\end{array}$ & AHP & [35] \\
\hline $\begin{array}{c}\text { Analyzing the sustainability of different concrete and reinforcement configurations for } \\
\text { segmental linings }\end{array}$ & AHP, MIVES & [36] \\
\hline Evaluating different stormwater drainage options for urban areas of arid regions & AHP, PROMETHEE II & [30] \\
\hline Developing the decision support system for the asset management of steel bridges & S-AHP (SMART, AHP) & [38] \\
\hline $\begin{array}{l}\text { Estimating the components of the } \\
\text { total cost of } A B C \text { versus conventional construction methods }\end{array}$ & TOPSIS, Fuzzy TOPSIS & [39] \\
\hline $\begin{array}{l}\text { Selection of the optimum solution for the seismic retrofitting of existing RC buildings } \\
\text { and for the super-elevation of existing masonry constructions }\end{array}$ & TOPSIS, ELECTRE, VIKOR & [40] \\
\hline $\begin{array}{l}\text { Establishing a cost-benefit approach } \\
\text { for the most suitable vertical addition solution }\end{array}$ & TOPSIS & [41] \\
\hline Finding the best compromise solution for effective vernacular architecture change & AHP, TOPSIS Grey & [42] \\
\hline Developing a methodological and systematic approach for building material selection & DEMATEL, FANP & [43] \\
\hline Selection of sustainable materials for building projects & FEAHP & [44] \\
\hline Selecting the most feasible highway construction method & ANP & [45] \\
\hline Location selection for roundabout construction & Rough BWM, Rough WASPAS & [46] \\
\hline $\begin{array}{l}\text { Sustainability assessment tool for analyzing reinforced concrete structural columns of } \\
\text { residential buildings }\end{array}$ & MIVES & [37] \\
\hline $\begin{array}{c}\text { Finding strategies for the prioritization and selection of heterogeneous } \\
\text { investments projects }\end{array}$ & MIVES & [32] \\
\hline $\begin{array}{l}\text { Assessment of properties of a fresh and hardened concrete by incorporating various } \\
\text { amounts of ceramic waste. }\end{array}$ & AHP, TOPSIS & [47] \\
\hline Creating a recreational building sustainability assessment model & AHP & [48] \\
\hline Building an effective evaluation model for green building construction methods & DEMATEL, ANP, ZOGP & [49] \\
\hline $\begin{array}{c}\text { Development of the methodology that serves as a decision support aid in assessing } \\
\text { project managers }\end{array}$ & AHP, ARAS & [50] \\
\hline $\begin{array}{l}\text { Selecting the most efficient procurement/delivery system for multiple contracts } \\
\text { power plants }\end{array}$ & SMART & [51] \\
\hline Indicating the worst passenger car parking conditions in residential areas & SAW, TOPSIS, COPRAS, AHP & [52] \\
\hline
\end{tabular}

Based on Table 2, it can be concluded that the AHP method is one of the most frequently applied. In addition, it appears that AHP, as well as other methods, can be synthesized with other MCDM methods, but also with other theories such as fuzzy and grey numbers.

\subsection{Supply Chain Management}

Supply chains present a very complex field involving many participants. The aim of the complete supply chain is to find an optimum from the perspective of all the participants, which is a rather complex task [53-55].

Supply chain management in terms of sustainability in a number of industries is an increasingly frequent topic of research. Therefore, this section provides an analysis of 22 articles on this topic. In the review by Seuring [56], MCDM, and particularly AHP, was listed as one of the quantitative methods for improving the supply chain management. Additionally, based on the review, it can be concluded that the social component of sustainability is paid the least attention. In their review paper, Zimmer et al. [57] analyzed the use of various models to support decision-making on sustainable supplier selection. The models that were stated as the most commonly used were the mathematical/analytic ones, which include MCDM. Significantly, the biggest percentage of application belongs to the AHP method, followed by ANP, etc. The selection of suppliers, according to many authors, is one of the most demanding problems of sustainable supply chain management. Therefore, numerous methods for ranking suppliers have been developed to date, and Fallahpour et al. [58] used the fuzzy modifications of the AHP and TOPSIS methods. The abovementioned authors used the fuzzy preferences programming (FPP) method to reach the relative weights of criteria, while the fuzzy TOPSIS method was used to rank suppliers. In order to validate the methods, a case study was conducted on a real system. The fuzzy approach in combination with the TOPSIS MCDM method was 
used by Govindan et al. [59] to assess the sustainable performance of suppliers. In order to perform the selection of suppliers in terms of sustainability and at the same time to take into account the business goals of the company, Dai and Blackhurst [60] presented an integrated approach based on AHP and the quality function deployment (QFD) method with four hierarchical phases. Rezaei et al. [61] presented a new methodology for the selection of suppliers consisting of three phases, where the central phase is the application of the BWM method of multi-criteria decision-making. The methodology presented can be particularly useful for companies that are looking for new markets. For the selection of suppliers, Azadnia et al. [62] proposed an integrated approach that, in addition to the fuzzy AHP method (FAHP), is based on multi-objective mathematical programming, as well as on rule-based weighted fuzzy method. According to Su et al. [63], the assessment of sustainable supply chain management and the selection of suppliers are performed using grey theory in combination with the DEMATEL method. Luthra et al. [64] presented an integrated approach to selecting suppliers consisting of a combination of AHP and VIKOR methods based on 22 criteria for all three aspects of sustainability. Because thermal power plants are the main source of electricity in China, it is necessary to make a selection of sustainable suppliers of raw materials in order to achieve sustainable development of the company. According to Zhao and Guo [65], an integrated approach is based on the fuzzy entropy-TOPSIS method. MCDM methods can be used to assess the degree of organizational sustainability of a company, as presented in [66]. Hsu et al. [67] presented a hybrid approach based on several MCDM methods in order to select suppliers in terms of carbon emissions. The observed framework for the selection of suppliers has been applied to the case of a hotel in Taiwan. A similar study was carried out by Kuo et al. [68] on the example of electronic industry. The evaluation of the supplier performance in the field of electronic industry in order to implement green supply chains is a topic of research in the study by Chatterjee et al. [17]. The authors used rough DEMATEL-ANP (R'AMATEL) in combination with rough multi-attribute ideal real comparative analysis ( $\mathrm{R}^{\prime} \mathrm{MAIRCA}$ ) method. Liu et al. [69] selected the suppliers of fresh products using the BWM and multi-objective optimization on the basis of the ratio analysis (MULTIMOORA) method.

Because innovation plays a very important role in sustainability, Gupta and Sarkis [70] presented a framework for ranking and selecting the criteria for sustainable innovations in supply chain management. This framework is based on the BWM method, and its applicability and efficiency were tested on several manufacturing companies in India. In their work, Validi et al. [71] dealt with the sustainability of the food supply chain. The TOPSIS method was used for the purpose of ranking the traffic routes, taking into account $\mathrm{CO}_{2}$ emissions and total transport costs.

A quantitative assessment of the performance of a sustainable supply chain was presented in Erol et al. [72] with regard to all three aspects of sustainability. Due to the presence of indeterminacy, it is very difficult to estimate certain criteria, which is why the authors used fuzzy techniques in addition to MCDM. More precisely, the fuzzy entropy and fuzzy MAUT methods were used. Das and Shaw [73] proposed a methodology based on the AHP and Fuzzy TOPSIS methods for selecting a sustainable supply chain, taking into account carbon emissions and various social factors. In the study by Entezaminia et al. [74], the AHP method was used to evaluate products in the supply chain according to environmental criteria such as recyclability, biodegradability, energy consumption, and product risk.

The application of information and communication technologies in supply chains can bring numerous benefits to an organization, and among the most important is sustainability. Luthra et al. [75] proposed the application of delphi and fuzzy DEMATEL methods for identifying and evaluating the guidelines for the application of these technologies in sustainable initiatives in supply chains. In Padhi et al. [76], a framework that identifies sustainable processes in supply chains for individual industries in India was presented. The ranking of industry branches was carried out using six fuzzy MCDM methods. Table 3 provides a summary of the applied MCDM methods for the sub-area of supply chain management. The decision-making process requires the prior definition and fulfillment of certain factors, especially when it comes to complex areas, such as supply chain management [77]. 
Table 3. MCDM methods in the sub-area of supply chain management.

\begin{tabular}{|c|c|c|}
\hline A Problem that Is Solved Using the MCDM Method & Applied Methods & Reference \\
\hline Sustainable supplier selection through a questionnaire-based survey & FPP, Fuzzy TOPSIS & [58] \\
\hline Investigating sustainable supply chains in manufacturing companies & BWM & [70] \\
\hline $\begin{array}{l}\text { Provision of optimized distribution routes based on carbon output and costs for the } \\
\text { demand side of a dairy supply chain producing milk products }\end{array}$ & TOPSIS & [71] \\
\hline $\begin{array}{l}\text { Development of the sustainability-focused supplier assessment methodology that will } \\
\text { be able to capture the 'voice of customer' at multiple stages in the supply chain and } \\
\text { translate the needs of the end customer back through the supply chain }\end{array}$ & AHP-QFD & [60] \\
\hline Proposing an innovative three-phase supplier selection methodology & BWM & [61] \\
\hline $\begin{array}{l}\text { Integrated approach of rule-based weighted fuzzy method, fuzzy analytical hierarchy } \\
\text { process, and multi-objective mathematical programming for sustainable } \\
\text { supplier selection }\end{array}$ & FAHP & [62] \\
\hline Identifying and analyzing criteria and alternatives in incomplete information & Grey-DEMATEL & [63] \\
\hline Evaluating the sustainable supplier selection & AHP, VIKOR & [64] \\
\hline Selecting the proper green supplier of thermal power equipment & Fuzzy Entropy-TOPSIS & [65], \\
\hline $\begin{array}{l}\text { Classification of the degree of sustainability of organizations that work in providing } \\
\text { supplies to the oil and gas industry }\end{array}$ & ELECTRE TRI & [66] \\
\hline $\begin{array}{c}\text { Evaluating the carbon and energy management performance of suppliers by using } \\
\text { multiple-criteria decision-making }\end{array}$ & $\begin{array}{l}\text { Fuzzy Delphi, DEMATEL, } \\
\text { DEMATEL-ANP (DANP), VIKOR }\end{array}$ & [67] \\
\hline $\begin{array}{l}\text { Novel hybrid multiple-criteria decision-making method for evaluating green suppliers } \\
\text { in an electronics company }\end{array}$ & DANP, DEMATEL, VIKOR & [68] \\
\hline Evaluating the performance of suppliers in the electronics industry & R'AMATEL, R'MAIRCA & [17] \\
\hline $\begin{array}{l}\text { Novel two-stage fuzzy integrated MCDM method for the selection of } \\
\text { suitable suppliers }\end{array}$ & BWM, MULTIMOORA & [69] \\
\hline Evaluating the sustainability performance of a supplier & Fuzzy TOPSIS & [59] \\
\hline Evaluating the sustainability performance of a supply chain & Fuzzy MAUT & [72] \\
\hline $\begin{array}{c}\text { Proposing an uncertain supply chain network design (SCND) model by considering } \\
\text { various carbon emissions and social factors }\end{array}$ & AHP, Fuzzy TOPSIS & [73] \\
\hline $\begin{array}{c}\text { Development of a new comprehensive multi-objective aggregate production planning } \\
\text { model in a green supply chain considering a reverse logistic network to be used in } \\
\text { many industries }\end{array}$ & AHP & [74] \\
\hline $\begin{array}{l}\text { Identification and evaluation of key drivers relevant to information and } \\
\text { communication technologies for sustainability initiatives in a supply chain }\end{array}$ & Delphi, Fuzzy DEMATEL & [75] \\
\hline $\begin{array}{l}\text { Identifying the significance of various sustainable supply chain processes on } \\
\text { firm performance }\end{array}$ & $\begin{array}{l}\text { Fuzzy TOPSIS, Fuzzy ELECTRE, Fuzzy } \\
\text { AHP, Fuzzy Multiplicative AHP, Fuzzy } \\
\text { SMART, Fuzzy VIKOR }\end{array}$ & [76] \\
\hline
\end{tabular}

In the sub-area of supply chain management, based on the table, it is apparent that most authors apply the AHP and TOPSIS methods. As mentioned in the previous section, their applications can be combined with other methods.

\subsection{Transport and Logistics}

As in other engineering disciplines, MCDM methods are also applied in the field of transport and logistics. This section provides a review of 23 articles dealing with the above issues. In Mardani et al. [78], a review of the methods used to solve problems in transport systems was provided. The articles were systematically categorized into 10 groups, one of which was sustainability. The authors stated that according to the number of articles published on MCDM in combination with sustainability, this category could be ranked sixth.

In Jeon et al. [79], the application of MCDM methods in selecting sustainable transport plans based on the sustainability index is examined. The weighted sum model (WSM) method was used. In their work, Cadena and Magro [80] presented a new methodology for assigning weight coefficients to sustainability criteria in transport projects. In order to solve the problem of inaccuracy and subjectivity, the REMBRANDT and Delphi methods were applied.

Because the traffic system is the lifeblood of every country and one of the basis for its economic development, Baric et al. [81] proposed the application of the AHP method in selecting the best road section design in urban conditions. The tested model on the real system showed reliable results. One of the disadvantages of the AHP method is that it requires a large number of inputs. In order to solve this problem, Inti and Tandon [82] presented a modified AHP method with the characteristics of the additive transitivity of fuzzy relations. The model was tested in the selection of contractors for the construction of transport infrastructure.

In order to improve transport sustainability, one of the solutions is the application of various alternative fuels and vehicle drives. Mitropoulos and Prevedouros [83], in this way, assessed the 
characteristics of vehicles using the sustainability index. The identified indicators were classified into five categories of sustainability—environment, technology, energy, economy, and users—followed by the application of the WSM method for their aggregation. Additionally, Mohamadabadi et al. [84] selected the type of fuel for vehicles based on three basic aspects of sustainability. The PROMETHEE method was used for the ranking of alternatives based on five criteria. Intermodal transport can greatly improve the sustainability of the transport system. It is necessary to select the optimum location of terminals in terms of different requirements of different participants in a transport process. Therefore, Zecevic et al. [85] proposed a new hybrid MCDM model for the location selection. Sustainable transport systems have become necessary nowadays, primarily in large cities due to various adverse environmental impacts. An approach to selecting the best alternative of transport systems based on 24 criteria, classified into three categories, was defined in a study by Awasthi et al. [86]. The approach consists of three steps, and the TOPSIS method is applied in combination with fuzzy theory in order to evaluate the criteria and the selection of an alternative. Castillo and Pitfield [87] proposed the evaluative and logical approach to sustainable transport indicator compilation (ELASTIC) framework for selecting the sustainability indicators of the transport system using the AHP and SAW methods. Although, in recent years, improvements have been evidently made to methods of transport planning, according to Lopez and Monzon [88], it is necessary to apply a multidisciplinary approach based on Geographic Information System (GIS) in order to increase the level of sustainability in transport. In addition, it is necessary to integrate multi-criteria decision-making methods within the proposed approach. In his work, Simongati [89] presented a model for the selection of FREIGHT INTEGRATOR with MCDM methods and sustainability indicators. The aforementioned term represents a provider of door-to-door transport services, using different modes of transport in an efficient and sustainable way. The selection of alternatives is based on SAW and PROMETHEE methods. The assessment of transport system sustainability of some European countries based on selected economic, environmental, and social indicators is presented in the work of Bojkovic et al. [90]. The ELECTRE I method has been used together with its modification based on the absolute significance threshold (AST). A framework for the selection of sustainable transport projects in urban areas of developing countries was proposed in the work of Jones et al. [91].

The selection of alternatives is based on the localized sustainability score index using the AHP method. In addition to the AHP method, in order to assess the sustainability of various transport solutions, such as mode sharing, multimodal transport, and intelligent transport systems, Awasthi and Chauhan [92] used the Dempster-Shafer theory in the proposed hybrid approach. While the AHP method serves primarily to rank the criteria based on the weights, the Dempster-Shafer theory allows the synthesis of multiple sources of information. Dimić et al. [93] developed a model for strategic transport management based on Strengths, Weakness, Opportunities, Treats (SWOT) analysis, fuzzy Delphi, and DEMATEL-ANP methods.

Sustainability is a very important concept in logistics, and reverse logistics as one of its subgroups can greatly improve efficiency and the environmental aspect of business. Wang et al. [94] presented a method for identifying the collection mode for used components. A hybrid approach based on AHP and entropy weight (AHP-EW) method was used to estimate the weights of particular criteria, while the multi-attributive border approximation area comparison (MABAC) method was used to rank the alternatives. Different initiatives for city logistics (e.g., the proper location of distribution centers) can significantly contribute to raising the level of sustainability in the city. That is precisely the subject of research in Awasthi and Chauhan [95]. The MCDM methods used in the work were AHP and Fuzzy TOPSIS. Mavi et al. [96], using the fuzzy step-wise weight assessment ratio analysis (SWARA) and fuzzy MOORA methods, selected a third-party provider of reverse logistics service in the plastics industry.

One of the most current problems in logistics and supply chains is the selection of the location of the logistics center in terms of sustainability. Rao et al. [97] used the fuzzy multi-attribute group decision-making (MAGDM) approach to address the problem. Turskis and Zavadskas [98] approached 
the problem of selecting the location of the logistics center with the fuzzy ARAS (ARAS-F) method, while Pamucar et al. [99] used the DEMATEL-MAIRCA method for the same purpose.

Logistics are closely linked to the processing industry. Therefore, it is necessary to identify the factors that influence their interaction. For this purpose, Jiang et al. [100] applied the grey DEMATEL-based ANP method (DANP). Table 4 provides a summary of the applied MCDM methods for the sub-area of transport and logistics.

Table 4. MCDM methods in the sub-area of transport and logistics.

\begin{tabular}{|c|c|c|}
\hline A Problem that Is Solved Using the MCDM Method & Applied Methods & Reference \\
\hline Selecting sustainable transport plans based on the sustainability index & WSM & [79] \\
\hline Assigning weight coefficients to the sustainability criteria in transport projects & REMBRANDT, Delphi & [80] \\
\hline Evaluating road section design in an urban environment & $\mathrm{AHP}$ & [81] \\
\hline Assessment of transportation vehicle characteristics. & WSM & [83] \\
\hline Ranking different renewable- and non-renewable-fuel-based vehicles & PROMETHEE & [84] \\
\hline Selection of the intermodal transport terminal location & $\begin{array}{l}\text { Fuzzy Delphi, Fuzzy Delphi ANP, } \\
\text { Fuzzy Delphi VIKOR }\end{array}$ & [85] \\
\hline Identifying and selecting a small subset of sustainable transport indicators & AHP, SAW & [87] \\
\hline Assessment model for transport infrastructure plans & REMBRANDT & [88] \\
\hline $\begin{array}{l}\text { Valuation and comparison model adjusted to the decision-making tasks of the } \\
\text { freight integrator }\end{array}$ & SAW, PROMETHEE & [89] \\
\hline Evaluation of transport-sustainability performance in some European countries. & $\begin{array}{l}\text { ELECTRE I, } \\
\text { Modified ELECTRE I }\end{array}$ & [90] \\
\hline Developing the model for strategic transport management & Fuzzy Delphi, DEMATEL-ANP & [93] \\
\hline Identifying the best collection mode for used components & AHP-EW, MABAC & [94] \\
\hline Hybrid approach for evaluating city logistics initiatives & AHP, Fuzzy TOPSIS & [95] \\
\hline $\begin{array}{l}\text { Evaluation of third-party reverse } \\
\text { logistic provider considering sustainability and risk factors }\end{array}$ & Fuzzy SWARA, Fuzzy MOORA & [96] \\
\hline Location selection of a city logistics center from a sustainability perspective & Fuzzy MAGDM & [97] \\
\hline Selecting the most suitable site for a logistics center among a set of alternatives & Fuzzy ARAS, AHP & [98] \\
\hline $\begin{array}{l}\text { Sustainable selection of a location for the } \\
\text { development of a multimodal logistics center }\end{array}$ & DEMATEL-MAIRCA & [99] \\
\hline Identifying interactions between manufacturing and logistics industries & Grey DANP & [100] \\
\hline
\end{tabular}

Table 4 indicates which MCDM methods are used in the field of transport and logistics. In this case, the AHP method is also the most applied MCDM method.

\subsection{Energy}

This section provides a review of the application of MCDM methods in the field of energy. 24 articles were analyzed, and the results have been given in textual and tabular formats. Developing renewable energy sources is a growing trend in the world on a day-to-day basis, especially when it comes to solar energy. The selection of an optimum location for the installation of photovoltaic systems is of great importance, because it can reduce the cost of the project and also ensure the maximum production of electricity. It sufficiently proves the high sustainability of such sources. Al Garni and Awasthi [101] selected the location of solar systems based on MCDM methods and GIS. The AHP method was used to evaluate the weights of feasibility criteria that directly affect the performance of the solar system. A similar study was also presented in the work of Diaz-Cuevas et al. [102], where spatial information instead of GIS was provided with the PostgreSQL-PostGIS database, which was based on Structured Query Language (SQL). The AHP method is used to determine the weights of the criteria. GIS is also necessary in selecting the location of wind farms that are also a very significant alternative source of energy. According to Sanchez-Lozano et al. [103], fuzzy MCDM methods are used to determine the weights of the criteria and the selection of an optimum alternative in solving this problem.

The selection of the optimum type of renewable energy sources using MCDM methods based on the hesitant fuzzy linguistic (HFL) term set was presented in the work of Buyukozkan and 
Karabulut [104]. The proposed methodology was tested using the example of the selection between several alternatives in the territory of Turkey. A similar study was presented in the work of Wu et al. [105], where a case study for China was conducted. Based on the AHP and TOPSIS methods, it was found that solar systems are the best solution. Yazdani et al. [18] presented a new hybrid approach for the selection of renewable energy technology, using DEMATEL, ANP, COPRAS, and WASPAS methods. Zhang et al. [106] used the improved MCDM method based on fuzzy measure and integral to select the "pure" form of energy between several alternatives. In their research, Troldborg et al. [107] dealt with the same issue and applied the PROMETHEE method. In their work, Klein and Whalley [108] selected between 13 renewable and non-renewable energy sources based on eight criteria. According to Tsoutsos et al. [109], the selection of an optimum renewable energy source in Crete, Greece was carried out with the PROMETHEE I and PROMETHEE II methods. Countries rich in fossil fuels are forced to seek alternative energy sources in order to reduce $\mathrm{CO}_{2}$ emissions. Pamucar et al. [110] applied the linguistic neutrosophic numbers pairwise-combinative distance-based assessment (LNN PW-CODAS) to select the optimum energy production technology in Libya. In Pamucar et al. [111], a model for the selection of a location for the construction of wind farms based on GIS in combination with two MCDM methods, BWM and MAIRCA, was presented.

Generated electricity planning is of great importance for the electric power system of a country. Mirjat et al. [112] proposed the application of the AHP method for assessing the sustainability of four types of energy models. A case study was carried out for Pakistan. The European Union is developing its energy plans, and MCDM methods find their application in the ranking of plans. According to Balezentis and Streimikiene [113], for this purpose, WASPAS, ARAS, and TOPSIS methods should be used. The selection of the best energy project between several alternatives, using MCDM methods, was considered in the work of Buyukozkan and Karabulut [104].

Because electric vehicles are becoming increasingly common on roads in the world, it is necessary to provide stations for charging them at optimum locations. Zhao and Li [114] presented a methodology based on MCDM methods. The criteria of the expanded concept of sustainability, which in addition to the traditional three aspects also includes technology, were selected based on fuzzy delphi, while the selection of the best alternative was performed using the fuzzy grey relation analysis (GRA)-VIKOR method. Guo and Zhao [115] dealt with the same issues. In order to eliminate subjectivity when selecting the location of charging stations, in addition to the basic criteria of sustainability, 11 sub-criteria were defined, in which the weights were determined on the basis of literature research, opinion of experts, and feasibility studies. The specific location selection was completed using the fuzzy TOPSIS method.

Nuclear energy implies low values of $\mathrm{CO}_{2}$ emissions into the atmosphere, which is necessary in terms of the concept of sustainability. Gao et al. [116] presented a framework for selecting the best option for a nuclear fuel cycle at a plant. In order to determine the weights of the criteria, fuzzy AHP and criteria importance through intercriteria correlation (CRITIC) were used, and the selection of alternatives was performed using the TOPSIS and PROMETHEE II methods. The selection of the optimum energy option for a thermal power plant was the subject of research in the work of Skobalj et al. [117]. The selection between seven alternatives, including revitalization and additional production by alternative energy sources, was performed on the basis of the sustainability index, which was determined by the analysis and synthesis of parameters under information deficiency (ASPID) method. The application of MCDM methods in order to select a sustainable energy solution has not been omitted even when it comes to hydroelectric power plants in the work of Vucijak et al. [118]. According to Streimikiene et al. [119], the selection between several alternative technologies for the sustainable production of electricity can be performed with the MULTIMOORA and TOPSIS methods (Barros et al. [120]). Maxim [121] also deals with the same issues in his work. He used a modified SWING method for ranking technologies. Energy is the key to the economic and social development of a particular area. In their work, Jovanovic et al. [122] proposed a new approach based on the predictions of different energy scenarios in urban areas and the application of MCDM methods for 
evaluating them. Biomass implies a multitude of resources, such as plant waste, animal waste, food waste, etc. Ioannou et al. [123] used MCDM methods in their research to select the location of a biomass power plant. Table 5 provides a summary of the applied MCDM methods for the sub-area of energy.

Table 5. MCDM methods in the sub-area of energy.

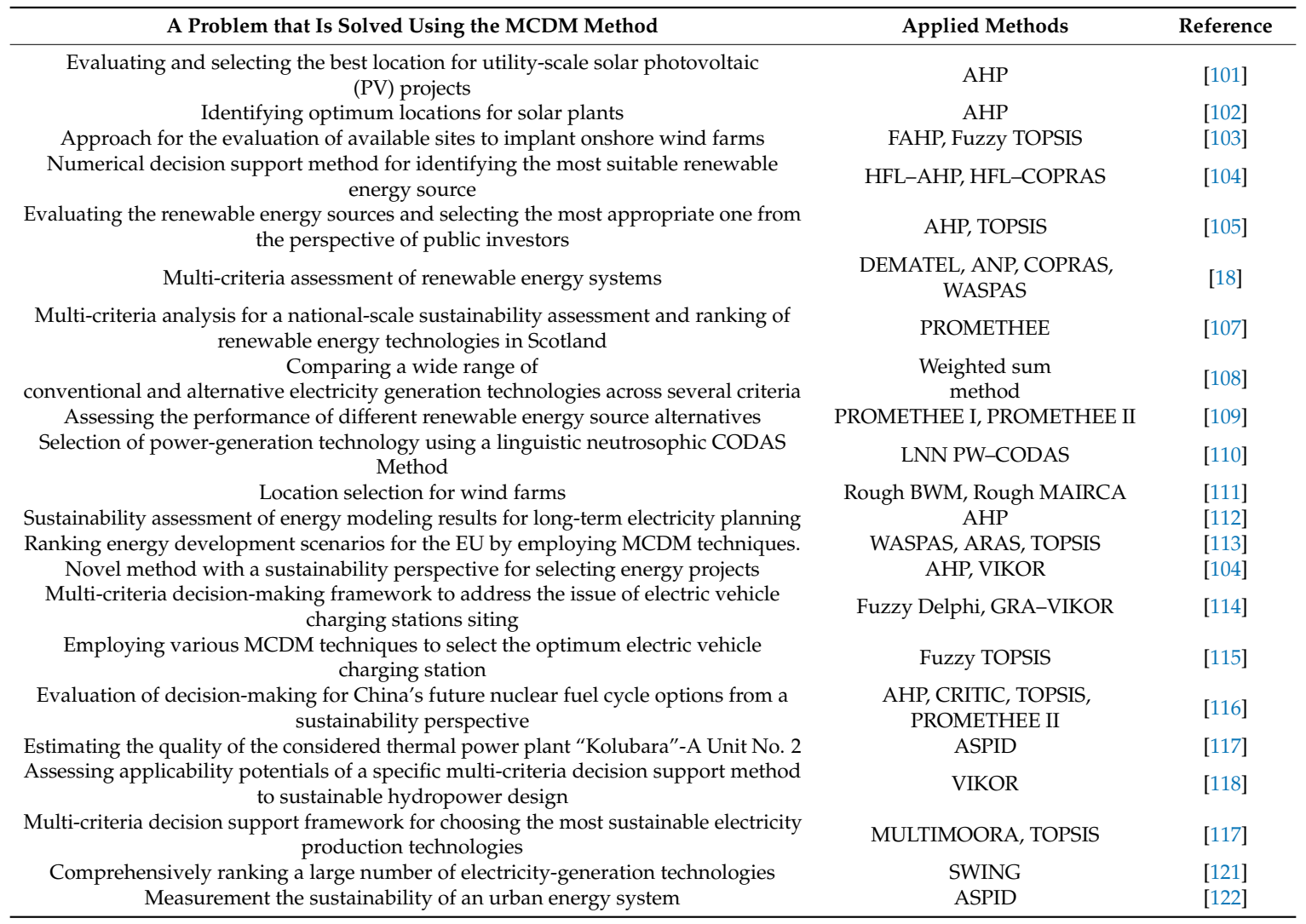

As can be seen from Table 5, in the field of energy, MCDM methods are mainly used to solve problems of selecting the optimum type of renewable and non-renewable energy sources. In most cases, the AHP method is applied.

\subsection{Other Engineering Disciplines}

In addition to four previously analyzed areas of the application of MCDM methods in sustainable engineering, uncategorized works are discussed in this section. This includes 13 articles from various fields of engineering, and their detailed analysis is given below. Creating a sustainable environmental management system is of great importance for reducing environmental pollution. Khalili and Duecker [124] created a system for selecting the best solution using the ELECTRE III method. In their research, Egilmez et al. [125] applied the intuitionistic fuzzy decision making (IFDM) approach, which is the integration of fuzzy logic and MCDM theory, in order to rank and select a city (in the US and Canada) with the highest degree of environmental sustainability. According to Alwaer and Clements-Croome [126], the model for the assessment of smart household sustainability includes the application of the AHP method. The level of sustainability of temporary housing units for the accommodation of persons after natural disasters can be assessed using the MIVES method according to Hosseini et al. [127]. A review of the MCDM methods used in assessing the sustainability of the system is shown in Diaz-Balteiro et al. [128], and it can be concluded that the AHP method takes the leading position in a number of applications. In Rosen et al. [129], a new method for assessing the sustainability of renewed contaminated surfaces was developed. The proposed sustainable choice of remediation (SCORE) method is a tool for selecting between several alternatives for possible 
land remediation. Ren et al. [130] developed a generic framework for the selection of sustainable technology for the treatment of sewage sludge in urban areas, using three MCDM methods: sum weighted method (SWM), digraph model, and TOPSIS. Using a MCDM method, Ren et al. [131] selected industrial systems from the aspect of sustainability. Because fossil fuel reserves are limited and atmospheric pollution is increasing, it is necessary to stimulate bio-diesel consumption. Sivaraja and Sakthivel [132] applied FAHP-TOPSIS, FAHP-VIKOR, and FAHP-ELECTRE to select the best blend of the specified fuel. In their research, Zavadskas et al. [133] selected the site for the incineration of waste, taking into account all the sustainability criteria using the new extension of the WASPAS method, the WASPAS single-valued neutrosophic Set (WASPAS-SVNS). It is known that the global population is growing each year, and it is necessary to provide an adequate amount of food. For this reason, Debnath et al. [134] selected the project portfolio for agricultural production by applying grey DEMATEL and MABAC methods. Huang et al. [135] presented a hybrid MCDM approach for the selection of materials for the production of particulate matter sensors. In their paper, Zhang et al. [136] dealt with the problem of evaluating the supply of rare minerals. For this purpose, fuzzy AHP and PROMETHEE methods were used. The application of the MCDM method within the decision support system can be of great importance to assist in emergency situations such as forest fires. The development of such a system is described in Ioannou et al. [137]. Table 6 provides a summary of the applied MCDM methods for the sub-area of other engineering disciplines.

Table 6. MCDM methods in the sub-area of other engineering disciplines.

\begin{tabular}{ccc}
\hline A Problem that Is Solved Using the MCDM Method & Applied Methods & Reference \\
\hline Proposing the design of the sustainable environmental management system & ELECTRE III \\
Sustainability performance assessment of 27 US and Canada metropolises & IFDM \\
Measuring the level of sustainability for sustainable intelligent buildings & AHP \\
Assessing the sustainability of post-disaster temporary housing units & MIVES \\
Technologies & SCORE \\
Assessing the sustainability of contaminated land remediation & {$[125]$} \\
[126] & {$[127]$} \\
Sustainability prioritization of industrial systems & SWM, Digraph model, TOPSIS \\
[128] & Fuzzy AHP, Fuzzy ANP, & PROMETHEE \\
[130] & Fuzzy AHP-TOPSIS, Fuzzy \\
AHP-VIKOR, Fuzzy & AHP-ELECTRE \\
Sustainable assessment of alternative sites for the construction of a waste & WASPAS-SVNS \\
incineration plant & [132] \\
Strategic project portfolio selection of agricultural byproducts & DEMATEL, MABAC \\
Evaluation and selection of materials for particulate matter sensors & DEMATEL, VIKOR \\
Enrichment evaluation to assess the security performance for China's several & Fuzzy AHP, PROMETHEE
\end{tabular}

The application of MCDM methods in other engineering disciplines is reduced to the environmental aspect of sustainability. Problems such as environmental pollution, soil contamination, air pollution, and the selection of the best fossil fuel are just a few that are solved by applying MCDM methods, of which AHP is most frequently used, according to Table 6.

\section{Conclusions}

In this paper, representative studies that include the application of multi-criteria decision-making models in the field of sustainability engineering have been presented. A review of about 108 studies related to the application of multi-criteria decision-making methods in the field of civil engineering and infrastructure, supply chain management, transport and logistics, energy, and other engineering disciplines provides interesting conclusions that can be useful for researchers who deal with the application of MCDM models in different engineering areas.

This literature review has shown that sustainable engineering is an area that is quite suitable for the use of MCDM. It is not surprising that the number of publications related to environmental protection, waste minimization, renewable energy sources, energy efficiency, and the concept of 
sustainability have tripled in the last decade. Switching to the concept of renewable energy has influenced researchers to try to exploit and improve available knowledge in decision-making.

Most of the methods used in sustainable engineering are based on traditional approaches with a noticeable trend of applying the theory of uncertainty, such as fuzzy, grey, rough, and neutrosophic theory. It can be said that the selection between existing MCDM methods is also a multi-criteria problem. Each of the methods has its advantages and disadvantages, and it is not possible to claim that any method is more suitable than others. The same applies to the selection of uncertainty theory for a considered multi-criteria problem. The choice of the method depends largely on the preferences of decision-makers and analysts. It is therefore important to consider the convenience, validity, and accessibility of methods for a problem considered. Mukhametzyanov and Pamucar [138] emphasize that the choice of method can significantly influence the decision-making process. They also emphasized that several methods should be used in a decision-making process in order to obtain a sustainable and high-quality decision. This is also an explanation of the observed trend of using a large number of methods in the literature. By analyzing the prior research presented in this review, it can be concluded that in the field of civil engineering and infrastructure, MCDM methods in most cases help to solve the problems that arise when selecting methods of building structures and roads. These problems attach great importance as objects require reinforcements in the case of seismic activities, and also, in the trend of the construction of green, ecological houses. In the sub-section of civil engineering and infrastructure there are 6 papers dealing with this topic, which amounts to $23.07 \%$ of the total. The most common method is AHP, which is used in 13 papers or $50 \%$ of the total. MCDM methods are most commonly used in this field in combination with fuzzy theory. A total of three papers $(11.54 \%)$ have been analyzed that integrate fuzzy principles along with other MCDM methods. In the field of supply chain management, the selection of the supplier is the most common problem that is solved using the MCDM method. It is necessary to select the most modern supplier in terms of sustainability, but also from the point of view of the customer or user of the service. Out of the total number of analyzed papers in this field, 11 or $50 \%$ deal with this problem, and the most commonly used methods are TOPSIS and AHP with 6 papers or $27.27 \%$ each. The combination of the MCDM method with the most common fuzzy theory is represented in 8 papers or in $36.36 \%$ of the total. The analysis has shown that the selection of the location of terminals and logistics centers from the aspect of sustainability is the most important problem that is solved by MCDM methods in the field of transport and logistics. Of the total number of articles in this field, 4 or $17.39 \%$ include a subject of research that is related to the choice of location. In this case, the AHP method is the most commonly applied. More precisely, it was applied in 7 papers or $30.43 \%$ of the total number. In this field, it is often a combination of MCDM methods with fuzzy theory. It is the same number as in the previous sub-area: 8 papers or $34.78 \%$ of the total. MCDM methods in the field of energy are used to a large extent for the choice of a certain type or mode of energy production. Alternatives most often include renewable but also conventional sources of energy. In this area there are 9 such papers, or $37.50 \%$ of the total, while the number of papers in which the AHP method is applied is 8 or $33.33 \%$. Fuzzy theory is most commonly combined with MCDM methods in this field and is present in 3 papers or $12.5 \%$ of the total. When it comes to other engineering disciplines, the application of the MCDM method is mainly to assess the sustainability of buildings, land, waste treatment technologies, and cities. Within the mentioned area, 6 papers dealing with this topic were analyzed, or $46.15 \%$ of the total number. The AHP method is also the most commonly applied in this field and is applied in 4 papers or $30.77 \%$ of the total. In addition, the application of fuzzy theory is used, along with the other methods. In this sub-area, fuzzy principles were applied in 3 papers or in $23.08 \%$ of the total.

Based on the analysis of papers and problems that are solved using the MCDM method, it can be concluded that the AHP method has the broadest application when it comes to sustainable engineering. Generally, the total number of papers involving the use of the AHP method was 38 or $35.19 \%$ of the total. Among the other theories that integrate with MCDM, fuzzy theory stands out in cases of uncertainty and imprecision with a total of 25 papers or $23.15 \%$ of the total. 
It can be concluded that there has been a significant increase in the application of MCDM models in all engineering areas in the last decade. The complexity of synchronous problems forces researchers to search for more flexible and simpler methods. Therefore, it is expected that there will be a further increase in works that consider the application of existing MCDM models and the development of new models for multi-criteria decision-making. It is also expected that the validation of results using multiple methods, the development of interactive systems to support the decision-making, and the improvement of fuzzy, grey, rough, and neutrosophic theory for the consideration of uncertainty will encourage researchers in the field of sustainable engineering to expand further research towards the creation of hybrid models, upgrading the existing MCDM models.

Author Contributions: Each author has participated and contributed sufficiently to take public responsibility for appropriate portions of the content.

Funding: This research received no external funding.

Conflicts of Interest: The authors declare no conflicts of interest.

\section{References}

1. Special Working Session. World Commission on Environment and Development; Oxford University Press: London, UK, 1987.

2. Hansmann, R.; Mieg, H.A.; Frischknecht, P. Principal sustainability components: Empirical analysis of synergies between the three pillars of sustainability. Int. J. Sustain. Dev. World Ecol. 2012, 19, 451-459. [CrossRef]

3. Moldan, B.; Janoušková, S.; Hák, T. How to understand and measure environmental sustainability: Indicators and targets. Ecol. Indic. 2012, 17, 4-13. [CrossRef]

4. Lozano, R. Envisioning sustainability three-dimensionally. J. Clean. Prod. 2008, 16, 1838-1846. [CrossRef]

5. Hutchins, M.J.; Sutherland, J.W. An exploration of measures of social sustainability and their application to supply chain decisions. J. Clean. Prod. 2008, 16, 1688-1698. [CrossRef]

6. Allenby, B.; Allen, D.; Davidson, C. Sustainable engineering: From myth to mechanism. Environ. Qual. Manag. 2007, 17, 17-26. [CrossRef]

7. Abraham, M.A. Principles of sustainable engineering. Sustain. Sci. Eng. Defin. Princ. 2006, 3-10. [CrossRef]

8. Pamucar, D.; Bozanic, D.; Lukovac, V.; Komazec, N. Normalized weighted geometric bonferroni mean operator of interval rough numbers-Application in interval rough DEMATEL-COPRAS. Facta Univ. Ser. Mech. Eng. 2018, 16, 171-191. [CrossRef]

9. Zolfani, S.H.; Pourhossein, M.; Yazdani, M.; Zavadskas, E.K. Evaluating construction projects of hotels based on environmental sustainability with MCDM framework. Alex. Eng. J. 2018, 57, 357-365. [CrossRef]

10. Zavadskas, E.K.; Antucheviciene, J.; Vilutiene, T.; Adeli, H. Sustainable Decision-Making in Civil Engineering, Construction and Building Technology. Sustainability 2018, 10, 14. [CrossRef]

11. Zavadskas, E.K.; Saparauskas, J.; Antucheviciene, J. Sustainability in Construction Engineering. Sustainability 2018, 10, 2236. [CrossRef]

12. Liu, F.; Aiwu, G.; Lukovac, V.; Vukic, M. A multicriteria model for the selection of the transport service provider: A single valued neutrosophic DEMATEL multicriteria model. Decis. Mak. Appl. Manag. Eng. 2018, 1, 121-130. [CrossRef]

13. Kianpour, K.; Jusoh, A.; Mardani, A.; Streimikiene, D.; Cavallaro, F.; Nor, K.M.; Zavadskas, E.K. Factors Influencing Consumers' Intention to Return the End of Life Electronic Products through Reverse Supply Chain Management for Reuse, Repair and Recycling. Sustainability 2017, 9, 1657. [CrossRef]

14. Mardani, A.; Zavadskas, E.K.; Streimikiene, D.; Jusoh, A.; Nor, K.M.D.; Khoshnoudi, M. Using fuzzy multiple criteria decision making approaches for evaluating energy saving technologies and solutions in five star hotels: A new hierarchical framework. Energy 2016, 117, 131-148. [CrossRef]

15. Chatterjee, P.; Mondal, S.; Boral, S.; Banerjee, A.; Chakraborty, S. A novel hybrid method for non-traditional machining process selection using factor relationship and Multi-Attributive Border Approximation Method. Facta Univ. Ser. Mech. Eng. 2017, 15, 439-456. [CrossRef]

16. Zolfani, S.H.; Zavadskas, E.K.; Khazaelpour, P.; Cavallaro, F. The Multi-Aspect Criterion in the PMADM Outline and Its Possible Application to Sustainability Assessment. Sustainability 2018, 10, 4451. [CrossRef] 
17. Chatterjee, K.; Pamucar, D.; Zavadskas, E.K. Evaluating the performance of suppliers based on using the R'AMATEL-MAIRCA method for green supply chain implementation in electronics industry. J. Clean. Prod. 2018, 184, 101-129. [CrossRef]

18. Yazdani, M.; Chatterjee, P.; Zavadskas, E.K.; Streimikiene, D. A novel integrated decision-making approach for the evaluation and selection of renewable energy technologies. Clean Technol. Environ. Policy 2018, 20, 403-420. [CrossRef]

19. Banasik, A.; Bloemhof-Ruwaard, J.M.; Kanellopoulos, A.; Claassen, G.D.H.; van der Vorst, J. Multi-criteria decision making approaches for green supply chains: A review. Flex. Serv. Manuf. J. 2018, 30, 366-396. [CrossRef]

20. Mardani, A.; Streimikiene, D.; Zavadskas, E.K.; Cavallaro, F.; Nilashi, M.; Jusoh, A.; Zare, H. Application of Structural Equation Modeling (SEM) to Solve Environmental Sustainability Problems: A Comprehensive Review and Meta-Analysis. Sustainability 2017, 9, 1814. [CrossRef]

21. Mardani, A.; Zavadskas, E.K.; Govindan, K.; Senin, A.A.; Jusoh, A. VIKOR Technique: A Systematic Review of the State of the Art Literature on Methodologies and Applications. Sustainability 2016, 8, 37. [CrossRef]

22. Mardani, A.; Zavadskas, E.K.; Khalifah, Z.; Zakuan, N.; Jusoh, A.; Nor, K.M.; Khoshnoudi, M. A review of multi-criteria decision-making applications to solve energy management problems: Two decades from 1995 to 2015. Renew. Sustain. Energy Rev. 2017, 71, 216-256. [CrossRef]

23. Mardani, A.; Zavadskas, E.K.; Streimikiene, D.; Jusoh, A.; Khoshnoudi, M. A comprehensive review of data envelopment analysis (DEA) approach in energy efficiency. Renew. Sustain. Energy Rev. 2017, 70, 1298-1322. [CrossRef]

24. Sierra, L.A.; Yepes, V.; Pellicer, E. A review of multi-criteria assessment of the social sustainability of infrastructures. J. Clean. Prod. 2018, 187, 496-513. [CrossRef]

25. Siksnelyte, I.; Zavadskas, E.K.; Streimikiene, D.; Sharma, D. An Overview of Multi-Criteria Decision-Making Methods in Dealing with Sustainable Energy Development Issues. Energies 2018, 11, 2754. [CrossRef]

26. Mardani, A.; Jusoh, A.; Zavadskas, E.K.; Cavallaro, F.; Khalifah, Z. Sustainable and Renewable Energy: An Overview of the Application of Multiple Criteria Decision Making Techniques and Approaches. Sustainability 2015, 7, 13947-13984. [CrossRef]

27. Allouhi, A.; El Fouih, Y.; Kousksou, T.; Jamil, A.; Zeraouli, Y.; Mourad, Y. Energy consumption and efficiency in buildings: Current status and future trends. J. Clean. Prod. 2015, 109, 118-130. [CrossRef]

28. Davidson, C.I.; Hendrickson, C.T.; Matthews, H.S.; Bridges, M.W.; Allen, D.T.; Murphy, C.F.; Allenby, B.R.; Crittenden, J.C.; Austin, S. Preparing future engineers for challenges of the 21st century: Sustainable engineering. J. Clean. Prod. 2010, 18, 698-701. [CrossRef]

29. Birgani, Y.T.; Yazdandoost, F. An Integrated Framework to Evaluate Resilient-Sustainable Urban Drainage Management Plans Using a Combined-adaptive MCDM Technique. Water Resour. Manag. 2018, 32, 2817-2835. [CrossRef]

30. Alhumaid, M.; Ghumman, A.R.; Haider, H.; Al-Salamah, I.S.; Ghazaw, Y.M. Sustainability Evaluation Framework of Urban Stormwater Drainage Options for Arid Environments Using Hydraulic Modeling and Multicriteria Decision-Making. Water 2018, 10, 581. [CrossRef]

31. Lombera, J.T.S.; Rojo, J.C. Industrial building design stage based on a system approach to their environmental sustainability. Constr. Build. Mater. 2010, 24, 438-447. [CrossRef]

32. Pujadas, P.; Pardo-Bosch, F.; Aguado-Renter, A.; Aguado, A. MIVES multi-criteria approach for the evaluation, prioritization, and selection of public investment projects. A case study in the city of Barcelona. Land Use Policy 2017, 64, 29-37. [CrossRef]

33. Del Cano, A.; Gomez, D.; de la Cruz, M.P. Uncertainty analysis in the sustainable design of concrete structures: A probabilistic method. Constr. Build. Mater. 2012, 37, 865-873. [CrossRef]

34. De la Fuente, A.; Pons, O.; Josa, A.; Aguado, A. Multi-Criteria Decision Making in the sustainability assessment of sewerage pipe systems. J. Clean. Prod. 2016, 112, 4762-4770. [CrossRef]

35. Akhtar, S.; Reza, B.; Hewage, K.; Shahriar, A.; Zargar, A.; Sadiq, R. Life cycle sustainability assessment (LCSA) for selection of sewer pipe materials. Clean Technol. Environ. Policy 2015, 17, 973-992. [CrossRef]

36. De la Fuente, A.; Blanco, A.; Armengou, J.; Aguado, A. Sustainability based-approach to determine the concrete type and reinforcement configuration of TBM tunnels linings. Case study: Extension line to Barcelona Airport T1. Tunn. Undergr. Space Technol. 2017, 61, 179-188. [CrossRef] 
37. Pons, O.; de la Fuente, A. Integrated sustainability assessment method applied to structural concrete columns. Constr. Build. Mater. 2013, 49, 882-893. [CrossRef]

38. Rashidi, M.; Ghodrat, M.; Samali, B.; Kendall, B.; Zhang, C.W. Remedial Modelling of Steel Bridges through Application of Analytical Hierarchy Process (AHP). Appl. Sci. 2017, 7, 168. [CrossRef]

39. Jia, J.M.; Ibrahim, M.; Hadi, M.; Orabi, W.; Xiao, Y. Multi-Criteria Evaluation Framework in Selection of Accelerated Bridge Construction (ABC) Method. Sustainability 2018, 10, 4059. [CrossRef]

40. Formisano, A.; Mazzolani, F.M. On the selection by MCDM methods of the optimal system for seismic retrofitting and vertical addition of existing buildings. Comput. Struct. 2015, 159, 1-13. [CrossRef]

41. Terracciano, G.; Di Lorenzo, G.; Formisano, A.; Landolfo, R. Cold-formed thin-walled steel structures as vertical addition and energetic retrofitting systems of existing masonry buildings. Eur. J. Environ. Civ. Eng. 2015, 19, 850-866. [CrossRef]

42. Siozinyte, E.; Antucheviciene, J.; Kutut, V. Upgrading the old vernacular building to contemporary norms: Multiple criteria approach. J. Civ. Eng. Manag. 2014, 20, 291-298. [CrossRef]

43. Khoshnava, S.M.; Rostami, R.; Valipour, A.; Ismail, M.; Rahmat, A.R. Rank of green building material criteria based on the three pillars of sustainability using the hybrid multi criteria decision making method. J. Clean. Prod. 2018, 173, 82-99. [CrossRef]

44. Akadiri, P.O.; Olomolaiye, P.O.; Chinyio, E.A. Multi-criteria evaluation model for the selection of sustainable materials for building projects. Autom. Constr. 2013, 30, 113-125. [CrossRef]

45. Ozcan-Deniz, G.; Zhu, Y.M. A multi-objective decision-support model for selecting environmentally conscious highway construction methods. J. Civ. Eng. Manag. 2015, 21, 733-747. [CrossRef]

46. Stevic, Z.; Pamucar, D.; Subotic, M.; Antucheviciene, J.; Zavadskas, E.K. The Location Selection for Roundabout Construction Using Rough BWM-Rough WASPAS Approach Based on a New Rough Hamy Aggregator. Sustainability 2018, 10, 2817. [CrossRef]

47. Rashid, K.; Razzaq, A.; Ahmad, M.; Rashid, T.; Tariq, S. Experimental and analytical selection of sustainable recycled concrete with ceramic waste aggregate. Constr. Build. Mater. 2017, 154, 829-840. [CrossRef]

48. Raslanas, S.; Kliukas, R.; Stasiukynas, A. Sustainability assessment for recreational buildings. Civ. Eng. Environ. Syst. 2016, 33, 286-312. [CrossRef]

49. Tsai, W.H.; Lin, S.J.; Lee, Y.F.; Chang, Y.C.; Hsu, J.L. Construction method selection for green building projects to improve environmental sustainability by using an MCDM approach. J. Environ. Plan. Manag. 2013, 56, 1487-1510. [CrossRef]

50. Zavadskas, E.K.; Vainiunas, P.; Turskis, Z.; Tamosaitiene, J. Multiple criteria decision support system for assessment of projects managers in construction. Int. J. Inf. Technol. Decis. Mak. 2012, 11, 501-520. [CrossRef]

51. Marzouk, M.; Elmesteckawi, L. Analyzing procurement route selection for electric power plants projects using SMART. J. Civ. Eng. Manag. 2015, 21, 912-922. [CrossRef]

52. Palevicius, V.; Paliulis, G.M.; Venckauskaite, J.; Vengrys, B. Evaluation of the requirement for passenger car parking spaces using multi-criteria methods. J. Civ. Eng. Manag. 2013, 19, 49-58. [CrossRef]

53. Stevic, Z.; Pamucar, D.; Vasiljevic, M.; Stojic, G.; Korica, S. Novel Integrated Multi-Criteria Model for Supplier Selection: Case Study Construction Company. Symmetry 2017, 9, 279. [CrossRef]

54. Puška, A.; Maksimović, A.; Stojanović, I. Improving organizational learning by sharing information through innovative supply chain in agro-food companies from Bosnia and Herzegovina. Oper. Res. Eng. Sci. Theory Appl. 2018, 1, 76-90. [CrossRef]

55. Fazlollahtabar, H. Operations and inspection Cost minimization for a reverse supply chain. Oper. Res. Eng. Sci. Theory Appl. 2018, 1, 91-107. [CrossRef]

56. Seuring, S. A review of modeling approaches for sustainable supply chain management. Decis. Support Syst. 2013, 54, 1513-1520. [CrossRef]

57. Zimmer, K.; Frohling, M.; Schultmann, F. Sustainable supplier management-A review of models supporting sustainable supplier selection, monitoring and development. Int. J. Prod. Res. 2016, 54, 1412-1442. [CrossRef]

58. Fallahpour, A.; Olugu, E.U.; Musa, S.N.; Wong, K.Y.; Noori, S. A decision support model for sustainable supplier selection in sustainable supply chain management. Comput. Ind. Eng. 2017, 105, 391-410. [CrossRef]

59. Govindan, K.; Khodaverdi, R.; Jafarian, A. A fuzzy multi criteria approach for measuring sustainability performance of a supplier based on triple bottom line approach. J. Clean. Prod. 2013, 47, 345-354. [CrossRef]

60. Dai, J.; Blackhurst, J. A four-phase AHP-QFD approach for supplier assessment: A sustainability perspective. Int. J. Prod. Res. 2012, 50, 5474-5490. [CrossRef] 
61. Rezaei, J.; Nispeling, T.; Sarkis, J.; Tavasszy, L. A supplier selection life cycle approach integrating traditional and environmental criteria using the best worst method. J. Clean. Prod. 2016, 135, 577-588. [CrossRef]

62. Azadnia, A.H.; Saman, M.Z.M.; Wong, K.Y. Sustainable supplier selection and order lot-sizing: An integrated multi-objective decision-making process. Int. J. Prod. Res. 2015, 53, 383-408. [CrossRef]

63. Su, C.M.; Horng, D.J.; Tseng, M.L.; Chiu, A.S.F.; Wu, K.J.; Chen, H.P. Improving sustainable supply chain management using a novel hierarchical grey-DEMATEL approach. J. Clean. Prod. 2016, 134, 469-481. [CrossRef]

64. Luthra, S.; Govindan, K.; Kannan, D.; Mangla, S.K.; Garg, C.P. An integrated framework for sustainable supplier selection and evaluation in supply chains. J. Clean. Prod. 2017, 140, 1686-1698. [CrossRef]

65. Zhao, H.R.; Guo, S. Selecting Green Supplier of Thermal Power Equipment by Using a Hybrid MCDM Method for Sustainability. Sustainability 2014, 6, 217-235. [CrossRef]

66. Barata, J.F.F.; Quelhas, O.L.G.; Costa, H.G.; Gutierrez, R.H.; Lameira, V.D.; Meirino, M.J. Multi-Criteria Indicator for Sustainability Rating in Suppliers of the Oil and Gas Industries in Brazil. Sustainability 2014, 6, 1107-1128. [CrossRef]

67. Hsu, C.W.; Kuo, T.C.; Shyu, G.S.; Chen, P.S. Low Carbon Supplier Selection in the Hotel Industry. Sustainability 2014, 6, 2658-2684. [CrossRef]

68. Kuo, T.C.; Hsu, C.W.; Li, J.Y. Developing a Green Supplier Selection Model by Using the DANP with VIKOR. Sustainability 2015, 7, 1661-1689. [CrossRef]

69. Liu, A.J.; Xiao, Y.X.; Ji, X.H.; Wang, K.; Tsai, S.B.; Lu, H.; Cheng, J.S.; Lai, X.J.; Wang, J.T. A Novel Two-Stage Integrated Model for Supplier Selection of Green Fresh Product. Sustainability 2018, 10, 2371. [CrossRef]

70. Gupta, H.; Sarkis, J. A supply chain sustainability innovation framework and evaluation methodology AU-Kusi-Sarpong, Simonov. Int. J. Prod. Res. 2018, 1-19. [CrossRef]

71. Validi, S.; Bhattacharya, A.; Byrne, P.J. A case analysis of a sustainable food supply chain distribution system-A multi-objective approach. Int. J. Prod. Econ. 2014, 152, 71-87. [CrossRef]

72. Erol, I.; Sencer, S.; Sari, R. A new fuzzy multi-criteria framework for measuring sustainability performance of a supply chain. Ecol. Econ. 2011, 70, 1088-1100. [CrossRef]

73. Das, R.; Shaw, K. Uncertain supply chain network design considering carbon footprint and social factors using two-stage approach. Clean Technol. Environ. Policy 2017, 19, 2491-2519. [CrossRef]

74. Entezaminia, A.; Heydari, M.; Rahmani, D. A multi-objective model for multi-product multi-site aggregate production planning in a green supply chain: Considering collection and recycling centers. J. Manuf. Syst. 2016, 40, 63-75. [CrossRef]

75. Luthra, S.; Mangla, S.K.; Chan, F.T.S.; Venkatesh, V.G. Evaluating the Drivers to Information and Communication Technology for Effective Sustainability Initiatives in Supply Chains. Int. J. Inf. Technol. Decis. Mak. 2018, 17, 311-338. [CrossRef]

76. Padhi, S.S.; Pati, R.K.; Rajeev, A. Framework for selecting sustainable supply chain processes and industries using an integrated approach. J. Clean. Prod. 2018, 184, 969-984. [CrossRef]

77. Stojic, G.; Stevic, Z.; Antucheviciene, J.; Pamucar, D.; Vasiljevic, M. A Novel Rough WASPAS Approach for Supplier Selection in a Company Manufacturing PVC Carpentry Products. Information 2018, 9, 121. [CrossRef]

78. Mardani, A.; Zavadskas, E.K.; Khalifah, Z.; Jusoh, A.; Nor, K.M.D. Multiple criteria decision-making techniques in transportation systems: A systematic review of the state of the art literature. Transport 2016, 31, 359-385. [CrossRef]

79. Jeon, C.M.; Amekudzi, A.A.; Guensler, R.L. Evaluating Plan Alternatives for Transportation System Sustainability: Atlanta Metropolitan Region. Int. J. Sustain. Transp. 2010, 4, 227-247. [CrossRef]

80. Cadena, P.C.B.; Magro, J.M.V. Setting the weights of sustainability criteria for the appraisal of transport projects. Transport 2015, 30, 298-306. [CrossRef]

81. Baric, D.; Pilko, H.; Strujic, J. An analytic hierarchy process model to evaluate road section design. Transport 2016, 31, 312-321. [CrossRef]

82. Inti, S.; Tandon, V. Application of Fuzzy Preference-Analytic Hierarchy Process Logic in Evaluating Sustainability of Transportation Infrastructure Requiring Multicriteria Decision Making. J. Infrastruct. Syst. 2017, 23, 04017014. [CrossRef]

83. Mitropoulos, L.K.; Prevedouros, P.D. Incorporating sustainability assessment in transportation planning: An urban transportation vehicle-based approach. Transp. Plan. Technol. 2016, 39, 439-463. [CrossRef] 
84. Mohamadabadi, H.S.; Tichkowsky, G.; Kumar, A. Development of a multi-criteria assessment model for ranking of renewable and non-renewable transportation fuel vehicles. Energy 2009, 34, 112-125. [CrossRef]

85. Zecevic, S.; Tadic, S.; Krstic, M. Intermodal Transport Terminal Location Selection Using a Novel Hybrid MCDM Model. Int. J. Uncertain. Fuzziness Knowl.-Based Syst. 2017, 25, 853-876. [CrossRef]

86. Awasthi, A.; Chauhan, S.S.; Omrani, H. Application of fuzzy TOPSIS in evaluating sustainable transportation systems. Expert Syst. Appl. 2011, 38, 12270-12280. [CrossRef]

87. Castillo, H.; Pitfield, D.E. ELASTIC - A methodological framework for identifying and selecting sustainable transport indicators. Transp. Res. Part D Transp. Environ. 2010, 15, 179-188. [CrossRef]

88. Lopez, E.; Monzon, A. Integration of Sustainability Issues in Strategic Transportation Planning: A Multi-criteria Model for the Assessment of Transport Infrastructure Plans. Comput.-Aided Civ. Infrastruct. Eng. 2010, 25, 440-451. [CrossRef]

89. Simongati, G. Multi-criteria decision making support tool for freight integrators: Selecting the most sustainable alternative. Transport 2010, 25, 89-97. [CrossRef]

90. Bojkovic, N.; Anic, I.; Pejcic-Tarle, S. One solution for cross-country transport-sustainability evaluation using a modified ELECTRE method. Ecol. Econ. 2010, 69, 1176-1186. [CrossRef]

91. Jones, S.; Tefe, M.; Appiah-Opoku, S. Proposed framework for sustainability screening of urban transport projects in developing countries: A case study of Accra, Ghana. Transp. Res. Part A Policy Pract. 2013, 49, 21-34. [CrossRef]

92. Awasthi, A.; Chauhan, S.S. Using AHP and Dempster-Shafer theory for evaluating sustainable transport solutions. Environ. Model. Softw. 2011, 26, 787-796. [CrossRef]

93. Dimić, S.; Pamučar, D.; Ljubojević, S.; Đorović, B. Strategic Transport Management Models-The Case Study of an Oil Industry. Sustainability 2016, 8, 954. [CrossRef]

94. Wang, H.; Jiang, Z.G.; Zhang, H.; Wang, Y.; Yang, Y.H.; Li, Y. An integrated MCDM approach considering demands-matching for reverse logistics. J. Clean. Prod. 2019, 208, 199-210. [CrossRef]

95. Awasthi, A.; Chauhan, S.S. A hybrid approach integrating Affinity Diagram, AHP and fuzzy TOPSIS for sustainable city logistics planning. Appl. Math. Model. 2012, 36, 573-584. [CrossRef]

96. Mavi, R.K.; Goh, M.; Zarbakhshnia, N. Sustainable third-party reverse logistic provider selection with fuzzy SWARA and fuzzy MOORA in plastic industry. Int. J. Adv. Manuf. Technol. 2017, 91, 2401-2418. [CrossRef]

97. Rao, C.J.; Goh, M.; Zhao, Y.; Zheng, J.J. Location selection of city logistics centers under sustainability. Transp. Res. Part D Transp. Environ. 2015, 36, 29-44. [CrossRef]

98. Turskis, Z.; Zavadskas, E.K. A new fuzzy additive ratio assessment method (aras-f). Case study: The analysis of fuzzy multiple criteria in order to select the logistic centers location. Transport 2010, 25, 423-432. [CrossRef]

99. Pamucar, D.S.; Tarle, S.P.; Parezanovic, T. New hybrid multi-criteria decision-making DEMATEL-MAIRCA model: Sustainable selection of a location for the development of multimodal logistics centre. Econ. Res.-Ekon. Istraživanja 2018, 31, 1641-1665. [CrossRef]

100. Jiang, P.; Hu, Y.C.; Yen, G.F.; Jiang, H.; Chiu, Y.J. Using a Novel Grey DANP Model to Identify Interactions between Manufacturing and Logistics Industries in China. Sustainability 2018, 10, 3456. [CrossRef]

101. Al Garni, H.Z.; Awasthi, A. Solar PV power plant site selection using a GIS-AHP based approach with application in Saudi Arabia. Appl. Energy 2017, 206, 1225-1240. [CrossRef]

102. Diaz-Cuevas, P.; Camarillo-Naranjo, J.M.; Perez-Alcantara, J.P. Relational spatial database and multi-criteria decision methods for selecting optimum locations for photovoltaic power plants in the province of Seville (southern Spain). Clean Technol. Environ. Policy 2018, 20, 1889-1902. [CrossRef]

103. Sanchez-Lozano, J.M.; Garcia-Cascales, M.S.; Lamata, M.T. GIS-based onshore wind farm site selection using Fuzzy Multi-Criteria Decision Making methods. Evaluating the case of Southeastern Spain. Appl. Energy 2016, 171, 86-102. [CrossRef]

104. Buyukozkan, G.; Karabulut, Y. Energy project performance evaluation with sustainability perspective. Energy 2017, 119, 549-560. [CrossRef]

105. Wu, Y.N.; Xu, C.B.; Zhang, T. Evaluation of renewable power sources using a fuzzy MCDM based on cumulative prospect theory: A case in China. Energy 2018, 147, 1227-1239. [CrossRef]

106. Zhang, L.; Zhou, P.; Newton, S.; Fang, J.X.; Zhou, D.Q.; Zhang, L.P. Evaluating clean energy alternatives for Jiangsu, China: An improved multi-criteria decision making method. Energy 2015, 90, 953-964. [CrossRef] 
107. Troldborg, M.; Heslop, S.; Hough, R.L. Assessing the sustainability of renewable energy technologies using multi-criteria analysis: Suitability of approach for national-scale assessments and associated uncertainties. Renew. Sustain. Energy Rev. 2014, 39, 1173-1184. [CrossRef]

108. Klein, S.J.W.; Whalley, S. Comparing the sustainability of US electricity options through multi-criteria decision analysis. Energy Policy 2015, 79, 127-149. [CrossRef]

109. Tsoutsos, T.; Drandaki, M.; Frantzeskaki, N.; Iosifidis, E.; Kiosses, I. Sustainable energy planning by using multi-criteria analysis application in the island of Crete. Energy Policy 2009, 37, 1587-1600. [CrossRef]

110. Pamucar, D.; Badi, I.; Sanja, K.; Obradovic, R. A Novel Approach for the Selection of Power-Generation Technology Using a Linguistic Neutrosophic CODAS Method: A Case Study in Libya. Energies 2018, 11, 2489. [CrossRef]

111. Pamucar, D.; Gigovic, L.; Bajic, Z.; Janosevic, M. Location Selection for Wind Farms Using GIS Multi-Criteria Hybrid Model: An Approach Based on Fuzzy and Rough Numbers. Sustainability 2017, 9, 1315. [CrossRef]

112. Mirjat, N.H.; Uqaili, M.A.; Harijan, K.; Mustafa, M.W.; Rahman, M.M.; Khan, M.W.A. Multi-Criteria Analysis of Electricity Generation Scenarios for Sustainable Energy Planning in Pakistan. Energies 2018, 11, 757. [CrossRef]

113. Balezentis, T.; Streimikiene, D. Multi-criteria ranking of energy generation scenarios with Monte Carlo simulation. Appl. Energy 2017, 185, 862-871. [CrossRef]

114. Zhao, H.R.; Li, N.N. Optimal Siting of Charging Stations for Electric Vehicles Based on Fuzzy Delphi and Hybrid Multi-Criteria Decision Making Approaches from an Extended Sustainability Perspective. Energies 2016, 9, 270. [CrossRef]

115. Guo, S.; Zhao, H.R. Optimal site selection of electric vehicle charging station by using fuzzy TOPSIS based on sustainability perspective. Appl. Energy 2015, 158, 390-402. [CrossRef]

116. Gao, R.X.; Nam, H.O.; Ko, W.I.; Jang, H. National Options for a Sustainable Nuclear Energy System: MCDM Evaluation Using an Improved Integrated Weighting Approach. Energies 2017, 10, 2017. [CrossRef]

117. Skobalj, P.; Kijevcanin, M.; Afgan, N.; Jovanovic, M.; Turanjanin, V.; Vucicevic, B. Multi-criteria sustainability analysis of thermal power plant Kolubara-A Unit 2. Energy 2017, 125, 837-847. [CrossRef]

118. Vucijak, B.; Kupusovic, T.; Midzic-Kurtagic, S.; Ceric, A. Applicability of multicriteria decision aid to sustainable hydropower. Appl. Energy 2013, 101, 261-267. [CrossRef]

119. Streimikiene, D.; Balezentis, T.; Krisciukaitiene, I.; Balezentis, A. Prioritizing sustainable electricity production technologies: MCDM approach. Renew. Sustain. Energy Rev. 2012, 16, 3302-3311. [CrossRef]

120. Barros, J.J.C.; Coira, M.L.; Lopez, M.P.D.; Gochi, A.D. Assessing the global sustainability of different electricity generation systems. Energy 2015, 89, 473-489. [CrossRef]

121. Maxim, A. Sustainability assessment of electricity generation technologies using weighted multi-criteria decision analysis. Energy Policy 2014, 65, 284-297. [CrossRef]

122. Jovanovic, M.; Afgan, N.; Bakic, V. An analytical method for the measurement of energy system sustainability in urban areas. Energy 2010, 35, 3909-3920. [CrossRef]

123. Ioannou, K.; Tsantopoulos, G.; Arabatzis, G.; Andreopoulou, Z.; Zafeiriou, E. A Spatial Decision Support System Framework for the Evaluation of Biomass Energy Production Locations: Case Study in the Regional Unit of Drama, Greece. Sustainability 2018, 10, 531. [CrossRef]

124. Khalili, N.R.; Duecker, S. Application of multi-criteria decision analysis in design of sustainable environmental management system framework. J. Clean. Prod. 2013, 47, 188-198. [CrossRef]

125. Egilmez, G.; Gumus, S.; Kucukvar, M. Environmental sustainability benchmarking of the US and Canada metropoles: An expert judgment-based multi-criteria decision making approach. Cities 2015, 42, 31-41. [CrossRef]

126. Alwaer, H.; Clements-Croome, D.J. Key performance indicators (KPIs) and priority setting in using the multi-attribute approach for assessing sustainable intelligent buildings. Build. Environ. 2010, 45, 799-807. [CrossRef]

127. Hosseini, S.M.A.; de la Fuente, A.; Pons, O. Multi-criteria decision-making method for assessing the sustainability of post-disaster temporary housing units technologies: A case study in Bam, 2003. Sustain. Cities Soc. 2016, 20, 38-51. [CrossRef]

128. Diaz-Balteiro, L.; Gonzalez-Pachon, J.; Romero, C. Measuring systems sustainability with multi-criteria methods: A critical review. Eur. J. Oper. Res. 2017, 258, 607-616. [CrossRef] 
129. Rosen, L.; Back, P.E.; Soderqvist, T.; Norrman, J.; Brinkhoff, P.; Norberg, T.; Volchko, Y.; Norin, M.; Bergknut, M.; Doberl, G. SCORE: A novel multi-criteria decision analysis approach to assessing the sustainability of contaminated land remediation. Sci. Total Environ. 2015, 511, 621-638. [CrossRef]

130. Ren, J.Z.; Liang, H.W.; Chan, F.T.S. Urban sewage sludge, sustainability, and transition for Eco-City: Multi-criteria sustainability assessment of technologies based on best-worst method. Technol. Forecast. Soc. Chang. 2017, 116, 29-39. [CrossRef]

131. Ren, J.Z.; Xu, D.; Cao, H.; Wei, S.A.; Dong, L.C.; Goodsite, M.E. Sustainability Decision Support Framework for Industrial System Prioritization. AIChE J. 2016, 62, 108-130. [CrossRef]

132. Sivaraja, C.M.; Sakthivel, G. Compression ignition engine performance modelling using hybrid MCDM techniques for the selection of optimum fish oil biodiesel blend at different injection timings. Energy 2017, 139, 118-141. [CrossRef]

133. Zavadskas, E.K.; Bausys, R.; Lazauskas, M. Sustainable Assessment of Alternative Sites for the Construction of a Waste Incineration Plant by Applying WASPAS Method with Single-Valued Neutrosophic Set. Sustainability 2015, 7, 15923-15936. [CrossRef]

134. Debnath, A.; Roy, J.; Kar, S.; Zavadskas, E.K.; Antucheviciene, J. A Hybrid MCDM Approach for Strategic Project Portfolio Selection of Agro By-Products. Sustainability 2017, 9, 1302. [CrossRef]

135. Huang, C.Y.; Chung, P.H.; Shyu, J.Z.; Ho, Y.H.; Wu, C.H.; Lee, M.C.; Wu, M.J. Evaluation and Selection of Materials for Particulate Matter MEMS Sensors by Using Hybrid MCDM Methods. Sustainability 2018, 10, 3451. [CrossRef]

136. Zhang, L.; Bai, W.; Yu, J.; Ma, L.M.; Ren, J.Z.; Zhang, W.S.; Cui, Y.Z. Critical Mineral Security in China: An Evaluation Based on Hybrid MCDM Methods. Sustainability 2018, 10, 4114. [CrossRef]

137. Ioannou, K.; Lefakis, P.; Arabatzis, G. Development of a decision support system for the study of an area after the occurrence of forest fire. Int. J. Sustain. Soc. 2011, 3, 5-32. [CrossRef]

138. Mukhametzyanov, I.; Pamucar, D. A sensitivity analysis in MCDM problems: A statistical approach. Decis. Mak. Appl. Manag. Eng. 2018, 1, 51-80. [CrossRef]

(C) 2019 by the authors. Licensee MDPI, Basel, Switzerland. This article is an open access article distributed under the terms and conditions of the Creative Commons Attribution (CC BY) license (http:/ / creativecommons.org/licenses/by/4.0/). 